\title{
16. MAJOR AND MINOR ELEMENT GEOCHEMISTRY OF SEDIMENTS FROM HOLE 379A, LEG 42B, DEEP SEA DRILLING PROJECT
}

\author{
S.E. Calvert and C.H. Batchelor, Institute of Oceanographic Sciences, Wormley, Godalming, Surrey GU8 5UB, U.K.
}

\section{INTRODUCTION}

A continuous section of the Pleistocene in the Black Sea provides an unusual opportunity to examine the changes in the hydrography and hydrochemistry of a basin reflected in the geochemistry of the accumulated sediments. A record of varying oxic lacustrine and anoxic marine conditions produced over the last 25,000 years by the Pleistocene fluctuations in sea level has been established as a result of detailed studies of the Recent sediments collected during cruise 49 of Atlantis II (Degens and Ross, 1974). Thus, anoxic marine waters filled the basin prior to 25,000 years B.P. after which time the Black Sea become isolated from the Mediterranean. The waters then became fresh and oxygenated for a period lasting until approximately 9000 years B.P. Marine waters started to spill over the Bosphorus sill as a result of the post-Würm sea-level rise and marine, anoxic conditions were re-established.

Sediments deposited during the lacustrine stage (25,000-9000 years B.P.) are principally terrigenous, laminated silts and clays containing about $15 \% \mathrm{CaCO}_{3}$ and less than $0.5 \%$ organic carbon. A distinct sapropel unit overlies the lacustrine muds, the base of which has been dated at 7000 years B.P. The sapropel is finely laminated, contains both coccoliths and authigenic aragonite and between $1 \%$ and $20 \%$ organic carbon. The unit marks the period when free $\mathrm{H}_{2} \mathrm{~S}$ was present in the deep water of the basin as a consequence of the stable density structure produced by the influx of saline waters into the lake. Above the sapropel is a laminated, carbonate-rich mud containing abundant coccoliths, mainly Emiliania huxleyi, representing the sediments deposited during the last 3000 years when essentially modern conditions had been established.

Chemical and mineralogical data on the recent Black Sea sediments have been reported by Hirst (1974). They highlight the contrasting lithologies of the sediments as described by Ross and Degens (1974) and illustrate some of the geochemical distinctions that can be made between the oxic and anoxic sediments of the basin.

\section{METHODS}

Samples representing 2-cm intervals were collected by P. Stoffers and E. Degens throughout the length of the core onboard Glomar Challenger. The sample intervals and depths, together with the laboratory code numbers which will be used throughout this report, are given in Table 1. The samples were received in an untreated state in sealed containers.

Portions of the sediments were dried at $100^{\circ} \mathrm{C}$ for 24 hours, ground in a tungsten carbide swing-mill, and homogenized. Major elements were determined by Xray emission spectrometry using a method similar to that described by Fabbi (1972). Subsamples of $300 \mathrm{mg}$ were mixed with $\mathrm{LiBO}_{2}(4.2 \mathrm{~g})$ and fused in graphite crucibles at $1000^{\circ} \mathrm{C}$ for 20 minutes. After cooling, weight losses were made up with Whatman chromatographic cellulose, the mixture ground in tungsten carbide and the powders pressed into $31-\mathrm{mm}$ diameter discs with a cellulose backing at 10 tons. Standards were G-2, BCR-1, AGV-1, and GSP-1 (U.S. Geological Survey); BR, GA, GH, UBN, DRN, MicaFe, and MicaMg (Centre de Récherches Pétrographiques et Géochimiques), NIM-G, -N, -P, -D, -L, and -S (South African National Institute of Metallurgy); TS, TB, and BM (Zentrales Geologisches Institut, Berlin); and SU1, UM-2, and UM-Y (Department of Energy, Ottawa). Instrumental conditions are given in Table 2.

The minor elements were also analyzed by X-ray emission using a modification of the method of Reynolds (1963) where the mass absorption coefficients of standards and samples are determined from the intensities of the Compton-scattered portion of the $\mathrm{K} \alpha$ characteristic line from a Mo anode using a LiF (220) analyzing crystal. Several standards, rather than a single standard as used by Reynolds, were used from a group of international standards listed above. These were supplemented by a series of synthetic standards, made by spiking a silicate rock powder with appropriate Specpure salts, for $\mathrm{Br}, \mathrm{Mo}$, and $\mathrm{Sr}$. Instrumental conditions used are given in Table 2.

Chlorine and sulfur were determined on unfused mixtures of samples and $\mathrm{LiBO}_{2}$ and $\mathrm{La}_{2} \mathrm{O}_{3}$ which were pressed into discs at 10 tons pressure. Standards were prepared by spiking a silicate base with $\mathrm{NaCl}$ and $\mathrm{K}_{2} \mathrm{SO}_{4}$. Chlorine was determined in order to derive a correction to the final analyses for the diluting effect of sea salt in the dried samples and the contribution of some major elements in the salt to the content of these same elements in the bulk sediment.

Precisions of the X-ray determinations are better than $3 \%$ for all elements except $\mathrm{Mg}( \pm 7 \%), \mathrm{P}( \pm 5 \%), \mathrm{Pb}$ $( \pm 6 \%)$, and As $( \pm 10 \%)$. Precision is poorer where minor element contents are less than $10 \mathrm{ppm}$.

Total carbon was determined by dry combustion in a Leco gravimetric carbon analyzer and carbonate carbon was determined by gravimetrically measuring the $\mathrm{CO}_{2}$ evolved from samples by hot $10 \% \mathrm{HCl}$ (see Kolpack and Bell, 1968). Organic carbon was estimated from the difference between these two measurements. Precision was $\pm 4 \%$ for both determinations.

The bulk mineralogy of all samples and the clay mineral composition of some selected samples were 
TABLE 1

Sample Numbers, Positions, Depths, and Water Contents at Hole $379 \mathrm{~A}$

\begin{tabular}{|c|c|c|c|c|c|}
\hline $\begin{array}{c}\text { Sample } \\
\text { No. }\end{array}$ & $\begin{array}{c}\text { Core } \\
\text { No. }\end{array}$ & $\begin{array}{c}\text { Section } \\
\text { No. }\end{array}$ & $\begin{array}{l}\text { Interval } \\
(\mathrm{cm})\end{array}$ & $\begin{array}{c}\text { Depth } \\
\text { (m) }\end{array}$ & $\begin{array}{c}\text { Water } \\
\text { Content }(\%)\end{array}$ \\
\hline 1 & 1 & 2 & $94-96$ & 2.45 & 34.4 \\
\hline 2 & 4 & 3 & $30-32$ & 29.31 & 34.1 \\
\hline 3 & 4 & 5 & $48-50$ & 32.49 & 32.7 \\
\hline 4 & 6 & 2 & $70-72$ & 47.21 & 34.2 \\
\hline 5 & 6 & 5 & $36-38$ & 51.37 & 25.7 \\
\hline 6 & 6 & 5 & $36-38$ & 51.37 & 22.5 \\
\hline 7 & 6 & 5 & $50-52$ & 51.51 & 17.2 \\
\hline 8 & 6 & 5 & $123-125$ & 52.24 & 38.6 \\
\hline 9 & 7 & 2 & $32-34$ & 56.33 & 34.8 \\
\hline 10 & 7 & 5 & $100-102$ & 61.51 & 30.4 \\
\hline 11 & 8 & 5 & $39-41$ & $70-40$ & 34.1 \\
\hline 12 & 9 & 2 & $30-32$ & 75.31 & 32.1 \\
\hline 13 & 9 & 4 & $64-66$ & 78.65 & 27.9 \\
\hline 14 & 9 & 5 & $60-62$ & 80.11 & 22.9 \\
\hline 15 & 10 & 2 & $15-17$ & 84.66 & 27.9 \\
\hline 16 & 10 & 5 & $81-83$ & 89.82 & 27.5 \\
\hline 17 & 11 & 2 & $79-81$ & 94.80 & 25.3 \\
\hline 18 & 11 & 4 & $63-65$ & 97.64 & 28.1 \\
\hline 19 & 11 & 5 & 55 & 99.05 & 37.4 \\
\hline 20 & 12 & 2 & $30-32$ & 103.81 & 28.9 \\
\hline 21 & 13 & 3 & $58-60$ & 115.09 & 23.1 \\
\hline 22 & 13 & 5 & $30-32$ & 117.81 & 29.0 \\
\hline 23 & 14 & 2 & $50-52$ & 123.01 & 25.5 \\
\hline 24 & 14 & 5 & $14-16$ & 127.15 & 25.0 \\
\hline 25 & 15 & 2 & $16-18$ & 132.17 & 23.9 \\
\hline 26 & 16 & 2 & $60-62$ & 142.11 & 19.4 \\
\hline 27 & 16 & 3 & $64-66$ & 143.65 & 23.4 \\
\hline 28 & 16 & 4 & $23-25$ & 144.74 & 27.6 \\
\hline 29 & 17 & 1 & $93-95$ & 150.44 & 27.2 \\
\hline 30 & 19 & 2 & $58-60$ & $170-59$ & 23.0 \\
\hline 31 & 21 & 2 & $50-52$ & 189.51 & 23.2 \\
\hline 32 & 21 & 6 & $17-19$ & 195.18 & 26.7 \\
\hline 33 & 22 & 2 & $18-20$ & 198.69 & 24.9 \\
\hline 34 & 22 & 4 & $101-103$ & 202.52 & 25.0 \\
\hline 35 & 22 & 6 & $14-16$ & 204.65 & 21.1 \\
\hline 36 & 23 & 2 & $22-24$ & 208.23 & 24.0 \\
\hline 37 & 23 & 6 & $18-20$ & 214.19 & 22.6 \\
\hline 38 & 24 & 6 & $85-87$ & 224.36 & 28.5 \\
\hline 39 & 29 & 3 & $34-36$ & 266.85 & 24.5 \\
\hline 40 & 34 & 2 & $91-93$ & 313.42 & 26.6 \\
\hline 41 & 34 & 4 & $101-103$ & 316.52 & 25.9 \\
\hline 42 & 35 & 5 & $107-109$ & 327.58 & 25.4 \\
\hline 43 & 38 & 4 & $80-82$ & 354.31 & 26.4 \\
\hline 44 & 39 & 5 & $35-37$ & 364.86 & 23.9 \\
\hline 45 & 40 & 2 & $60-62$ & 370.11 & 22.2 \\
\hline 46 & 42 & 1 & $124-126$ & 380.75 & 22.7 \\
\hline 47 & 47 & 4 & $135-137$ & 430.86 & 20.4 \\
\hline 48 & 49 & 1 & $13-15$ & 444.14 & 19.1 \\
\hline 49 & 50 & 3 & $19-21$ & 456.70 & 23.3 \\
\hline 50 & 51 & 6 & $110-112$ & 471.61 & 19.1 \\
\hline 51 & 52 & 1 & $88-90$ & 473.39 & 21.1 \\
\hline 52 & 54 & 2 & $43-45$ & 493.44 & 20.4 \\
\hline 53 & 58 & 4 & $104-106$ & 535.05 & 17.4 \\
\hline 54 & 59 & 3 & $83-85$ & 542.84 & 19.4 \\
\hline 55 & 59 & 5 & $86-88$ & 545.87 & 21.6 \\
\hline 56 & 60 & 4 & $43-45$ & 553.44 & 19.2 \\
\hline 57 & 60 & 4 & $125-127$ & 554.26 & 17.6 \\
\hline 58 & 66 & 2 & $72-74$ & 598.23 & 19.4 \\
\hline 59 & 68 & 5 & $80-82$ & 621.81 & 17.2 \\
\hline
\end{tabular}

determined by standard X-ray diffraction spectrometric methods using $\mathrm{Cu}$ radiation and a graphite monochromator.

\section{RESULTS}

Visual examination of the samples, and the X-ray diffraction data, demonstrate that the sediments at
TABLE 2

Conditions Used for Major and Minor Element Analyses by X-Ray Emission Methods

\begin{tabular}{|c|c|c|c|c|c|c|}
\hline Element & Line & Tube & Crystal $^{\mathrm{a}}$ & Counter $^{\mathrm{b}}$ & Vacuum & $\begin{array}{l}\text { Sample } \\
\text { Prep. }^{\mathrm{c}}\end{array}$ \\
\hline $\mathrm{Si}$ & $\mathrm{K} \alpha$ & $\mathrm{Cr}$ & PE & F & Yes & F \\
\hline Al & $\mathrm{K} \alpha$ & $\mathrm{Cr}$ & T1AP & $\mathrm{F}$ & Yes & F \\
\hline $\mathrm{Ti}$ & $\mathrm{K} \alpha$ & $\mathrm{Cr}$ & $\operatorname{LiF}(200)$ & $\mathrm{F}$ & Yes & $\mathrm{F}$ \\
\hline $\mathrm{Fe}$ & $\mathrm{K} \alpha$ & W & $\operatorname{LiF}(200)$ & $\mathrm{F}+\mathrm{S}$ & Yes & $\mathrm{F}$ \\
\hline $\mathrm{Ca}$ & $\mathrm{K} \alpha$ & $\mathrm{Cr}$ & $\mathrm{PE}$ & $\mathrm{F}$ & Yes & $\mathrm{F}$ \\
\hline $\mathrm{Mg}$ & $\mathrm{K} \alpha$ & $\mathrm{Cr}$ & T1AP & $\mathrm{F}$ & Yes & $\mathrm{F}$ \\
\hline$K^{\circ}$ & $\mathrm{K} \alpha$ & $\mathrm{Cr}$ & $\mathrm{PE}$ & $\mathrm{F}$ & Yes & $\mathrm{F}$ \\
\hline $\mathrm{P}$ & $\mathrm{K} \alpha$ & $\mathrm{Cr}$ & $\mathrm{Ge}$ & $\mathrm{F}$ & Yes & F \\
\hline Mn & $\mathrm{K} \alpha$ & W & $\operatorname{LiF}(200)$ & $\mathrm{F}$ & Yes & $\mathrm{F}$ \\
\hline $\mathrm{S}$ & $\mathrm{K} \alpha$ & $\mathrm{Cr}$ & T1AP & $\mathrm{F}$ & Yes & PD \\
\hline $\mathrm{C} 1$ & $\mathrm{~K} \alpha$ & $\mathrm{Cr}$ & T1AP & $\mathrm{F}$ & Yes & PD \\
\hline As & $\mathrm{K} \beta$ & Mo & $\operatorname{LiF}(200)$ & $\mathrm{S}$ & No & $P$ \\
\hline $\mathrm{Ba}$ & $\mathrm{K} \alpha$ & W & $\operatorname{Lif}(200)$ & $\mathrm{S}$ & No & P \\
\hline $\mathrm{Br}$ & $\mathrm{K} \alpha$ & Mo & $\operatorname{LiF}(200)$ & $\mathrm{S}$ & No & P \\
\hline $\mathrm{Cu}$ & $\mathrm{K} \alpha$ & W & $\operatorname{LiF}(200)$ & $\mathrm{S}$ & No & $\mathrm{P}$ \\
\hline I & $\mathrm{K} \alpha$ & W & $\operatorname{LiF}(200)$ & $\mathrm{S}$ & No & $\mathbf{P}$ \\
\hline Mo & $\mathrm{K} \alpha$ & W & $\operatorname{LiF}(200)$ & $\mathrm{S}$ & No & $P$ \\
\hline $\mathrm{Ni}$ & $\mathrm{K} \alpha$ & W & $\operatorname{LiF}(200)$ & $\mathrm{S}$ & No & P \\
\hline $\mathrm{Pb}$ & $L \beta$ & Mo & $\operatorname{LiF}(200)$ & $\mathrm{S}$ & No & $P$ \\
\hline $\mathrm{Rb}$ & $\mathrm{K} \alpha$ & Mo & $\operatorname{LiF}(220)$ & $\mathrm{S}$ & No & $\mathrm{P}$ \\
\hline $\mathrm{Sr}$ & $\mathrm{K} \alpha$ & W & $\operatorname{LiF}(200)$ & $\mathrm{S}$ & No & P \\
\hline $\mathrm{Y}$ & $\mathrm{K} \alpha^{\mathrm{d}}$ & Mo & $\operatorname{LiF}(200)$ & $\mathrm{S}$ & No & P \\
\hline $\mathrm{Zn}$ & $\mathrm{K} \alpha$ & W & $\operatorname{LiF}(200)$ & $\mathrm{S}$ & No & P \\
\hline $\mathrm{Zr}_{\mathrm{r}}$ & $\mathrm{K} \alpha^{\mathrm{e}}$ & W & $\operatorname{LiF}(200)$ & $\mathrm{S}$ & No & $\mathbf{P}$ \\
\hline
\end{tabular}

${ }^{\mathrm{a}} \mathrm{PE}=$ Pentaerythritol; TIAP $=$ Thallium Acid Phthalate $; \mathrm{Ge}=$ German ium (111); $\mathrm{LiF}=$ Lithium fluoride (200 and 220).

$b_{F}=$ flow proportional counter; $6 \mu \mathrm{m}$ window for all elements except $\mathrm{Al}$ and $\mathrm{Mg}$ where a $1 \mu \mathrm{m}$ window was used.

$\mathrm{S}=$ Scintillation counter. $150 \mu \mathrm{m}$ collimator used throughout.

${ }^{\mathrm{C}} \mathrm{F}=$ fused sample; $\mathrm{PD}=$ sample powder diluted with $\mathrm{La}_{2} \mathrm{O}_{3}$ and

$\mathrm{LiO}_{2}$.

${ }^{\mathrm{d}}$ Corrected for contribution from Rb K $\beta$.

${ }^{\mathrm{e}}$ Corrected for contribution from $\mathrm{Sr} \mathrm{K} \beta$.

Hole $379 \mathrm{~A}$ are for the most part terrigenous silty clays containing quartz, feldspar, calcite, chlorite, and mica with minor amounts of montmorillonite, hornblende, pyrite, and aragonite. There are occasional sands, consisting mostly of quartz and feldspar, a sapropel, and a moderately organic-rich, calcareous clay in the samples examined. The chemical data reflect the overwhelmingly terrigenous character of the sediments; a considerable amount of variation in bulk composition is brought about by the laminated nature of the sediments and by the sampling of clay and sand layers and carbonate and clay layers in various sections of the cores.

\section{Carbonate}

Carbonate contents (Table 3) range between $2.25 \%$ and $34.43 \%$ of the total sediment. For the most part, the carbonate is calcite; aragonite occurs in Sample 19 (Plate 1). Authigenic calcite is present in the deeper parts of the hole (Plate 1; and see Stoffers and Degens, this volume). Dolomite was not detected in any sample and this is confirmed by the absence of anomalously high $\mathrm{MgO}$ values. Vertical trends in $\mathrm{CaCO}_{3}$ are not clear (Figure 1); a considerable amount of variability is most probably due to the sampling of mixtures of biogenous, detrital, and authigenic carbonate and aluminosilicate debris. This is clearly demonstrated by adjacent samples at 316 and 327 meters which contain $31.86 \%$ and $2.25 \% \mathrm{CaCO}_{3}$, respectively. 
TABLE 3

Major and Minor Element Composition of Sediments, Hole 379A, Leg 42B, Deep Sea Drilling Project.

Major Elements in Weight \%; Minor Elements in ppm; Analyses Corrected for Dilution by, and Contributions From, Sea Salt

\begin{tabular}{|c|c|c|c|c|c|c|c|c|c|c|c|c|c|c|c|c|c|c|c|c|c|c|c|c|c|}
\hline $\begin{array}{c}\text { Sample } \\
\text { Number }\end{array}$ & $\mathrm{SiO}_{2}$ & ${ }_{2} \mathrm{O}_{3}$ & $\mathrm{TiO}_{2}$ & ${ }_{2} \mathrm{O}_{3}{ }^{*}$ & $\mathrm{CaO}$ & $\mathrm{MgO}$ & $\mathrm{K}_{2} \mathrm{O}$ & $\mathrm{P}_{2} \mathrm{O}_{5}$ & ino & $\mathbf{S}$ & $\mathrm{CO}_{2}$ & C & As & $\mathrm{Ba}$ & $\mathrm{Br}$ & $\mathrm{Cu}$ & 1 & Mo & $\mathrm{Ni}$ & $\mathrm{Pb}$ & $\mathbf{R b}$ & Sr & $Y$ & $\mathrm{Zn}$ & $\mathrm{Zr}$ \\
\hline 1 & 47.06 & 13.48 & 0.69 & 6.74 & 11.58 & 3.95 & 2.00 & 0.22 & 0.15 & 0.24 & 8.73 & 0.40 & 6 & 479 & 13 & 48 & & 10 & 55 & 25 & 79 & 268 & 27 & 93 & 117 \\
\hline 2 & 4 & 13.49 & 69 & $\therefore$ & 37 & 66 & 2.04 & 0.19 & 13 & 0.17 & 7.80 & 0.49 & 10 & 520 & 12 & 47 & 1 & 9 & 58 & 24 & 79 & 67 & 26 & 91 & 122 \\
\hline 3 & 47.91 & 3.82 & 74 & 18 & 5 & 35 & 08 & 0.19 & 18 & 0.15 & 7.66 & 0.45 & 11 & 50 & 8 & so & & 10 & 6 & 25 & 82 & 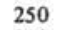 & 29 & 133 & 123 \\
\hline 4 & 49.99 & 14.67 & 0.67 & 75 & 12 & 15 & 2.34 & 0.24 & 15 & 0.22 & 6.77 & 0.83 & 9 & 531 & 18 & 50 & 8 & 10 & 52 & 24 & 95 & 210 & 39 & 99 & 130 \\
\hline 5 & 54.39 & 14.80 & 0.58 & 66 & 8.07 & 2.35 & 2.18 & 0.23 & 11 & 1.17 & 4.95 & 0.71 & 5 & 589 & 15 & 46 & & 17 & 27 & 24 & 72 & 345 & 26 & 88 & 117 \\
\hline 6 & 55.80 & 15.29 & 0.61 & 6.12 & 7.61 & 2.73 & 2.24 & 0.21 & 11 & 1.12 & 4.44 & 0.72 & 6 & 598 & 15 & 46 & & 16 & 26 & 24 & 71 & 331 & 25 & 87 & 116 \\
\hline 7 & 60.72 & 14.71 & 0.61 & 5.58 & 6.44 & 2.68 & 1.96 & 0.21 & 0.10 & 0.14 & 3.52 & 0.22 & 1 & 638 & 5 & 43 & & 8 & 26 & 21 & 60 & 342 & 26 & 82 & 136 \\
\hline 8 & 36.75 & 11.46 & 0.38 & 0 & 20.75 & 2.70 & 1.92 & 0.18 & 0.10 & 1.35 & 15.15 & 1.89 & i & 481 & 62 & 54 & 3 & 35 & 39 & 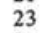 & . & & 27 & 94 & 71 \\
\hline 9 & 47.02 & 14.73 & 0.65 & 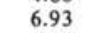 & 9.90 & 3.20 & 2.23 & 0.19 & 0.14 & 0.28 & 7.26 & 1.19 & 6 & 540 & 20 & 56 & 11 & 10 & 43 & 8 & & & 31 & 103 & 117 \\
\hline 10 & 50.56 & 14.82 & 0 & 53 & 9.12 & 2.72 & 2.33 & 0.19 & 0.12 & 0.20 & 6.89 & 0.64 & 9 & 5 & 13 & 46 & 4 & 10 & & 3 & 97 & & 29 & 95 & 125 \\
\hline 11 & 5. & 1 & 0 & 6.3 & 8.00 & 2 & 2.51 & 0 & 0. & 0.40 & 6.16 & 0 & 1 & 5 & 18 & 48 & 3 & 11 & 0 & 5 & 10 & & & 0 & 137 \\
\hline 12 & 4 & 1 & 0 & & 10.55 & 3 & 2.10 & 0 & 0. & 1 & 7. & 1 & 1 & 46 & 20 & 50 & 8 & 13 & 52 & 5 & 0 & 69 & & 92 & 118 \\
\hline 13 & 4 & 14 & 0. & & 10.54 & 3 & 2 & 0 & & 1.24 & 7.74 & 0.96 & 3 & 46 & 19 & 49 & 1 & 12 & 54 & 21 & 83 & 279 & 25 & 95 & 110 \\
\hline 14 & St & 14.68 & 0.64 & & 98 & 2.75 & 2.26 & 0.21 & 5 & 1.33 & 3.74 & 1.28 & 2 & 519 & 27 & 47 & & 11 & 30 & 26 & 84 & 223 & 32 & 95 & 157 \\
\hline 15 & 53.08 & 15.83 & 0.64 & & 7.36 & 2.91 & 2.33 & 0.22 & 0.15 & 1.68 & 4.84 & 0.79 & 5 & 536 & 11 & 51 & & 13 & 29 & 26 & 77 & 269 & 29 & 95 & 122 \\
\hline 16 & 51.26 & 14.44 & 0.66 & 6.62 & 8.52 & 3.53 & 2.39 & 0.16 & 0.14 & 1.21 & 6.29 & 0.73 & 6 & 500 & 13 & 47 & & 13 & 51 & 24 & 90 & & & 94 & 133 \\
\hline 17 & 55.81 & 14.98 & 0.59 & & 7.34 & 2.45 & 2.09 & 0.20 & 0.10 & 1.01 & 4.40 & 0.72 & 5 & 58 & 13 & 45 & & & & & & & & & 121 \\
\hline 18 & 46 & 15.80 & 0.67 & 6.7 & 8.49 & 2.28 & 2.67 & 0.20 & 0.12 & 0.80 & 6.77 & 0.96 & 8 & 586 & 26 & 50 & & 13 & & & & & & & 29 \\
\hline 19 & 31 & 10. & 0 & & 11.67 & 1.75 & 1.52 & 0.3 & & & 10.68 & 14.75 & 86 & 472 & 237 & 97 & 13 & 175 & 67 & 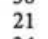 & & & & 82 & 79 \\
\hline 20 & 51 & 1 & 0 & & 8.42 & 3.51 & 2 & 0.2 & & & 6.20 & 54 & 8 & 520 & 13 & 62 & 1 & 10 & 56 & 4 & 95 & & 32 & 100 & 129 \\
\hline 21 & & 1 & 0 & & 12.06 & 353 & 1.84 & 0. & & & 8.76 & 0.40 & 12 & 48 & 8 & 47 & & & 59 & 22 & 6 & 280 & 30 & 86 & 127 \\
\hline 22 & & & & & & & & 0 . & & 0 & 5.87 & 0.47 & 5 & 51 & 13 & 50 & & 10 & 53 & 22 & 82 & 230 & 29 & 92 & 129 \\
\hline 23 & & .29 & 7 & & 10.28 & 3. & 2. & 0.17 & 0.12 & 0. & 7.47 & 0.35 & 9 & 51 & & 45 & 1 & 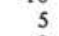 & 56 & 21 & 82 & 251 & 30 & 89 & 125 \\
\hline 24 & 65 & .20 & 8 & 6.83 & 9.95 & 3.78 & 2.13 & 0.21 & 0.12 & 0.1 & 7.21 & 0.45 & 5 & 49 & 3 & 48 & & 3 & 59 & 26 & 8 & 245 & 3 & 91 & 125 \\
\hline 25 & 57.51 & 14.89 & 65 & .00 & 7.12 & 2.50 & 2.06 & 0.23 & 0.11 & 0.1 & 4.46 & 0.29 & 5 & 61 & 8 & 44 & & 10 & 34 & & 6 & & 2 & 82 & 132 \\
\hline 26 & 72.40 & 9.37 & 0.39 & 3.58 & 4.18 & 1.67 & 1.21 & 0.17 & 0.09 & 0.1 & 3.33 & 0.25 & 14 & 41 & 7 & 34 & & & & & 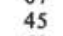 & & & 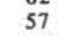 & 32 \\
\hline 27 & 69.40 & 11.13 & 0.47 & 4.54 & 3.98 & 2.40 & 1. & 0.1 & & & 2. & 0. & 14 & 4. & 9 & 39 & & 10 & & & & & & & 29 \\
\hline 28 & & & & & & & & & & & 2 & & . & & 10 & 43 & 1 & 9 & & & & & & 104 & 06 \\
\hline 29 & & & & & 5 & & & c & & & 4 & 8 & 15 & 5 & 0 & 51 & & 11 & 72 & 7 & 8 & & 31 & 95 & 135 \\
\hline 30 & & & & & & & & & & & 7.41 & 0.31 & 8 & 45 & 9 & 49 & & & 64 & 25 & & & 31 & 92 & 136 \\
\hline 3 & & & & & 8. & 2 & 2 & & & & 5.71 & 0 . & 12 & $5 e$ & 8 & 51 & & 1 & & 29 & 8 & 3 & 32 & 94 & 126 \\
\hline 3 & & & & & 11.75 & & 1. & c & & 0.1 & 8.86 & 0. & 13 & 47 & 10 & 49 & & & & 24 & 1 & & 2 & 88 & 115 \\
\hline 33 & & & & & 70 & 4 & 2. & & 0 & 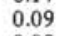 & 5.34 & 0.57 & 6 & 51 & 10 & 52 & 2 & 9 & & . & 9 & & 2 & 9 & 115 \\
\hline 34 & & & & & & 3. & 2. & & & & 5.45 & 0.59 & 15 & 5 & 11 & 49 & & 10 & & & 10 & & & 9 & 142 \\
\hline 35 & & & & & 12.00 & 3. & 1. & & & & 9. & & 1 & 4 & $\pi$ & 47 & & & & & & & & & \\
\hline 36 & & & & & 12.54 & 3 . & & & & & 10 & & 1 & & 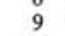 & $\begin{array}{l}40 \\
48\end{array}$ & & & & & & & & & 12 \\
\hline 37 & & & & & & 4. & & & & & & & 12 & & & & 1 & & & & & & & & \\
\hline 38 & & & & & & & & & & & & & $\epsilon$ & & & & & & & & & & & & 08 \\
\hline 39 & & & & & & & & & & & & & 10 & $4 \varepsilon$ & 10 & 46 & 4 & 10 & 65 & 2 & & & & & 109 \\
\hline 40 & & & & & & & & & & & 10. & & 8 & 5 & 14 & 52 & 13 & 8 & & & 9 & & & & 92 \\
\hline 4 & & & & & & & & & & & 14 & & 3 & 5 & 1 & 48 & 3 & I & & & & & & & 87 \\
\hline 4 & & & & & & & & & & & & & 2 & 5 & $i$ & 50 & $s$ & 9 & 5 & 3 & 18 & & & 10 & 30 \\
\hline & & & & & & & & & & & & & 7 & 5 & 1 & 41 & & 9 & 2 & 6 & 13 & & & & 142 \\
\hline & & & & & & & & & & & 3 & & 5 & 5 & 1 & 49 & & 9 & 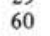 & 23 & & & & & \\
\hline & & & & & & & & & & & 10. & & 4 & 4 & 1 & 47 & & 11 & & & & & & & \\
\hline & & & & & 11.2 & 3. & 2. & & & & 8 & & 8 & 4 & & 4 & 6 & & & & & & & & \\
\hline 4 & 5 & i & & & 9. & & 2. & & & & 7 & & 15 & & & 4 & & 1 & & & & & & & \\
\hline 4 & & & & & 12 & & & & & & & & 7 & 4 & & & & 8 & & & & & & & 14 \\
\hline & & & & & & & & & & & & & 6 & 1 & & & & 8 & & & & & & & 03 \\
\hline 5 & & & & & & & & & & & & & 5 & 4 & & & 4 & & & & & & & & 108 \\
\hline & & & & & & & & & & & & & 1 & & & 4 & & 9 & & & & & & & 06 \\
\hline & & & & & & & & & & & & & 3 & & & 51 & & 9 & & 3 & & & & 91 & 94 \\
\hline & & & & & & & & & & & 11 & 0. & 3 & & & 43 & & 10 & 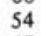 & 23 & & & & 83 & 105 \\
\hline & & & & & 14. & 3. & 1. & & 0 & 0 & 11 . & 0. & 6 & 5 & 1 . & 48 & & 11 & 3 & 25 & 74 & & & & \\
\hline 5 & & 1 & 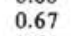 & 6. & 9. & 3. & 2. & 0 & & 0 & 7 & & 1 & 4 & & 5 & & 0 & & & & & & & \\
\hline & 4 & i & & & 13. & & 1. & & & & & & 1 & & & & & 10 & & & & & & & \\
\hline & & 1 & & & & & & & & & & & 1 & 46 & & 43 & & & & & & & & & 30 \\
\hline & & & & & & & & & & & & & 2 & & & 43 & & & & & & & & & 20 \\
\hline & & & 0. & 3.02 & 12.39 & 3.49 & 1.66 & 0.17 & 0.14 & 0.21 & 8.98 & 0.79 & & 507 & 23 & 48 & & 10 & 52 & 20 & 54 & 326 & 24 & 90 & 100 \\
\hline
\end{tabular}




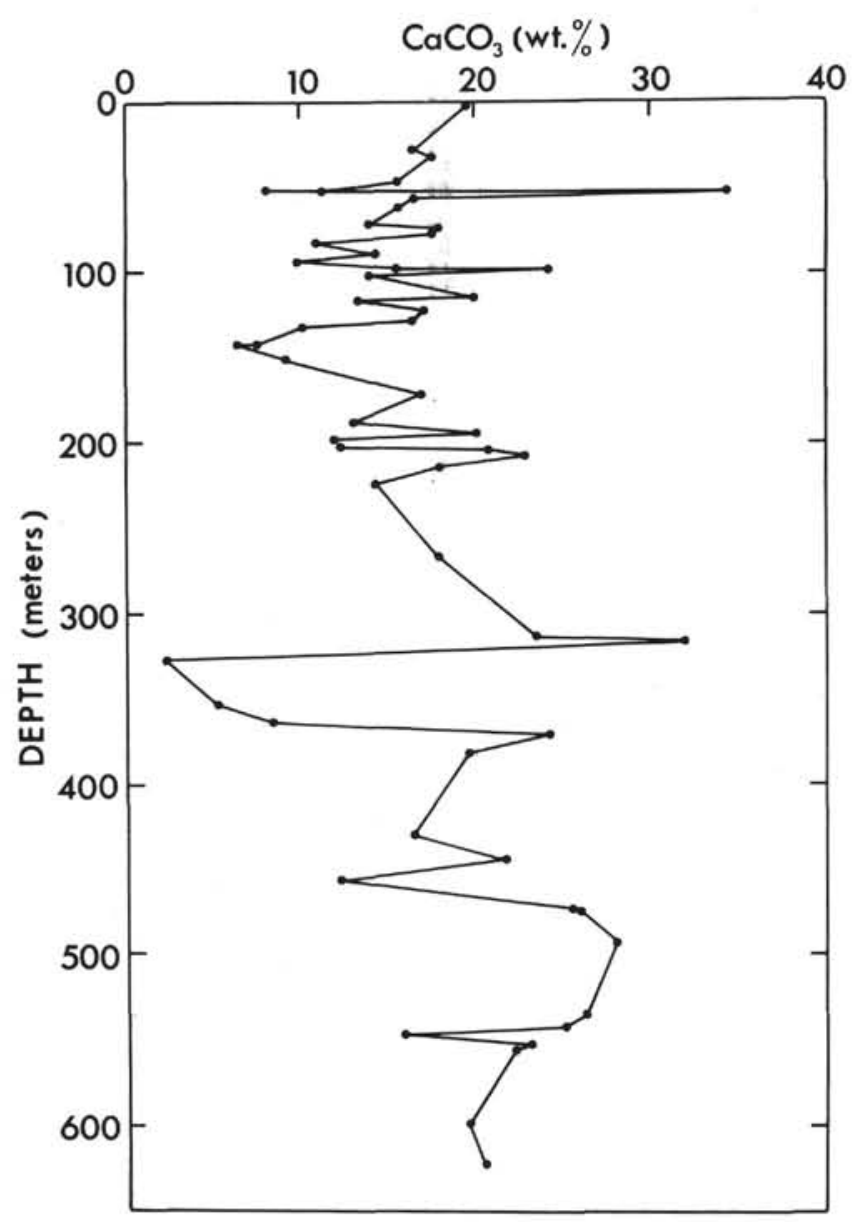

Figure 1. Distribution of $\mathrm{CaCO}_{3}$ contents at Hole $379 \mathrm{~A}$.

In spite of the scatter, carbonate values generally decrease from the surface to about 140 meters depth where sandy sediments occur. Below 140 meters the carbonate values increase to 316 meters and then fall abruptly immediately below this depth.where carbonate-poor clays are found. Below 370 meters, no trends are evident.

The relationship between $\mathrm{CaO}$ and $\mathrm{CO}_{2}$ (Figure 2) shows that most sample points fall close to a line representing pure $\mathrm{CaCO}_{3}$ with a small intercept on the abscissa representing the amount of $\mathrm{CaO}$ in the aluminosilicate fraction. However, a small group of samples, identified by their sample numbers, fall below this line. These samples contain much higher amounts of plagioclase feldspar than the other sediments, producing a slight $\mathrm{CaO}$ anomaly. Using the criteria of Slemmons (1962) and Peterson and Goldberg (1962) it can be shown that the plagioclase is mainly oligoclaseandesine, with $\triangle 2 \theta(131-131) \mathrm{CuK} \alpha$ of about 1.50 .

The plagioclase-bearing samples are also clearly separated on a plot of $\mathrm{Sr}$ and $\mathrm{CaO}$ (Figure 3 ) where the majority of the points fall on a line representing the $\mathrm{Sr} / \mathrm{Ca}$ relationship in calcite with approximately 350 ppm Sr. According to Ribbe and Smith (1966), $\mathrm{Sr}$ contents of plagioclase feldspars are highest in the range $\mathrm{An}_{20-40}$, increasing with increasing $\mathrm{Na}$ content and falling abruptly in albites. The composition of the plagioclase in the sediments from Hole $379 \mathrm{~A}$ is consistent with this relationship.

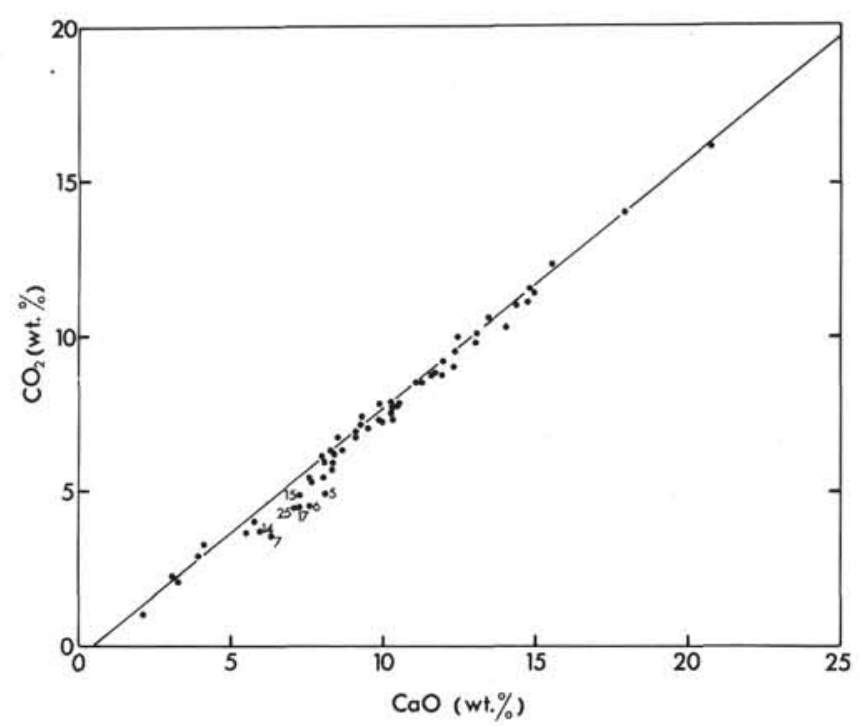

Figure 2. Relationship between $\mathrm{CaO}$ and $\mathrm{CO}_{2}$ contents of the sediments. Numbers are sample numbers as given in Tables 1 and 3.

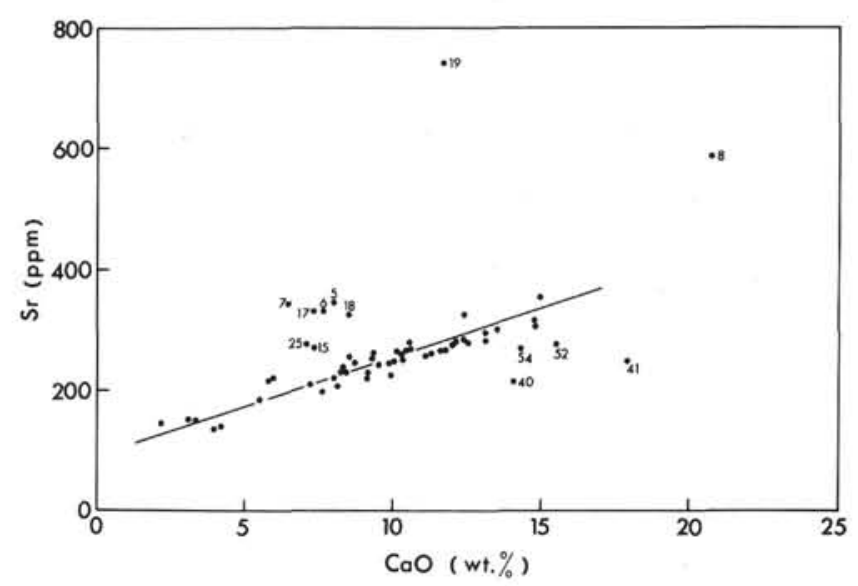

Figure 3. Relationship between $\mathrm{CaO}$ and $\mathrm{Sr}$ contents of the sediments. Numbers are sample numbers as given in Tables 1 and 3.

Two other groups of samples can be identified in Figure 3. Of those also having higher $\mathrm{Sr}$ contents, Sample 8 contains abundant coccoliths (Plate 1, Figure 1) and Sample 19 contains both aragonite and coccoliths of a different type (Plate 1, Figures 2 and 3). The aragonite grains are roughly $8 \times 30 \mu \mathrm{m}$ in size and are similar to those in the Recent Black Sea sapropels (Degens and Ross, 1972). The higher Sr content of Sample 19 is consistent with the presence of aragonite (Kinsman, 1969), while the slightly higher Sr content of Sample 8 can be accounted for adequately by the presence of approximately $30 \%$ by weight coccoliths having an $\mathrm{Sr}$ content of $1500 \mathrm{ppm}$ (Thompson and Bowen, 1969).

The remaining group is represented by Samples 40, 41,52 , and 54, having anomalously low $\mathrm{Sr}$ contents. These samples may contain a relatively higher proportion of detrital carbonate which is deficient in $\mathrm{Sr}$ due to recrystallization (see Kinsman, 1969; Sayles and Manheim, 1975), or the $\mathrm{Sr}$ anomaly may be produced 
by the presence of authigenic calcite (Plate I, Figure 4) which contains lower amounts of this element.

\section{Aluminosilicates}

Inspection of the chemical data in Table 3 and the matrix of correlation coefficients in Table 4 show that there are two co-varying groups of elements representing different types of terrigenous aluminosilicates, and a smaller group representing sands. The $\mathrm{SiO}_{2} / \mathrm{Al}_{2} \mathrm{O}_{3}$ ratio varies between 2.82 and 7.73 throughout the core, most values falling close to a value of 3.3 , typical of shales (Krauskopf, 1967) and near-shore terrigenous clays (Hirst, 1962). Samples 7, 26, 27, 40, 53, and 59 contain more quartz and have correspondingly higher $\mathrm{SiO}_{2} / \mathrm{Al}_{2} \mathrm{O}_{3}$ ratios. The amount of diatom opal in the sediments is quite low throughout the core so that the variation in $\mathrm{SiO}_{2} / \mathrm{Al}_{2} \mathrm{O}_{3}$ ratios shown in Figure 4 is considered to be due to the presence of variable amounts of fine-grained quartz in moderately clayey sediments. In the upper part of the hole, the ratio appears to vary around a mean value of 3.5 ; below 350 meters depth there is an irregular increase in the ratio with depth.

The high degree of correlation between $\mathrm{K}_{2} \mathrm{O}, \mathrm{Al}_{2} \mathrm{O}_{3}$, $\mathrm{Fe}_{2} \mathrm{O}_{3}, \mathrm{Rb}, \mathrm{Pb}, \mathrm{Ba}, \mathrm{Y}$, and $\mathrm{Zn}$ is probably accounted for by the presence of potassium feldspar and mica, significant mineral species in the bulk sediments. The relationships between $\mathrm{K}_{2} \mathrm{O}$ and $\mathrm{Al}_{2} \mathrm{O}_{3}$ and between $\mathrm{Fe}_{2} \mathrm{O}_{3}$ and $\mathrm{Al}_{2} \mathrm{O}_{3}$ are shown in Figures 5 and 6. A greater amount of scatter in Figure 6 is brought about by the presence of variable amounts of pyrite and other Fe-bearing phases of variable composition, whereas most of the $\mathrm{K}$ in the sediment is held in a smaller number of phases. Rubidium substitutes readily for $\mathrm{K}$ in aluminosilicates (Horstmann, 1957; Heier, 1962; Heier and Adams, 1964) and the relationship between the two elements is shown in Figure 7. The sediments have $\mathrm{K} / \mathrm{Rb}$ ratios clustering around 220 , slightly lower than the crustal average (Taylor, 1965), but consistent with a slight enrichment of $\mathrm{Rb}$ relative to $\mathrm{K}$ in weathered clays.

Barium occurs predominately in $\mathrm{K}$-bearing feldspars rather than in plagioclase (Smith and Ribbe, 1966; Ribbe and Smith, 1966), where it substitutes for K (Heier, 1962), but does not enter micas to a significant degree (Taylor, 1965). Hence, Ba values reflect fairly closely the variations in alkali feldspar content. Samples 5, 6, 7, 17, and 25 have significantly higher $\mathrm{Ba} / \mathrm{Rb}$ ratios than the other samples; these samples also contain more plagioclase feldspar (see Figures 2 and 3 ).

The presence of a second aluminosilicate in the sediments is shown by the close degree of correlation between $\mathrm{MgO}, \mathrm{Fe}_{2} \mathrm{O}_{3}, \mathrm{TiO}_{2}$, and $\mathrm{Ni}$. This group is controlled by the amount of chlorite which is an Fe-rich variety, using the criteria of Petruk (1964), similar to that present in modern sediments (Müller and Stoffers, 1974). The relationship between $\mathrm{MgO}$ and $\mathrm{Ni}$ shown in Figure 8 illustrates the high degree of correlation between the two elements. Two samples, the sapropel (19) and a sand (26), have higher $\mathrm{Ni} / \mathrm{MgO}$ ratios due to the contribution of $\mathrm{Ni}$ to the sediment by organic matter and/or sulfide (see below) and by a Ni-bearing sand-sized heavy mineral, possibly hornblende, respectively.

\section{Organic Carbon and Sulfides}

Variations in the organic carbon and total S contents are shown in Figure 9. The fluctuations correlate very well in the upper 250 meters of the core where several horizons rich in pyrite and organic matter occur. An extreme sample is the sapropel (Sample 19) at 99 meters depth which contains $14.75 \% \mathrm{C}$ and $1.81 \% \mathrm{~S}$. This sample also has the highest concentrations of $\mathrm{As}, \mathrm{Br}$, $\mathrm{Cu}, \mathrm{Mo}, \mathrm{P}$, and $\mathrm{Mn}$, and somewhat higher concentrations of $\mathrm{I}, \mathrm{Ni}$, and $\mathrm{Zn}$. It is quite similar to the sapropels in the Recent Black Sea sediments (Hirst, 1974) although the $\mathrm{S}$ values are much lower at Hole 379A. The minor metals $\mathrm{Cu}, \mathrm{Mo}, \mathrm{Ni}$, and $\mathrm{Zn}$ are probably present in both organic material and pyrite (Korolev, 1968; Volkov and Fomina, 1971, 1974; Pilipchuk and Volkov, 1968a, b). The $\mathrm{Br}$ and I, on the other hand, are present entirely in the organic fraction of the sediment (Price et al., 1970; Price and Calvert, 1973).

Sample 8, which is not separately identified in the Initial Core Descriptions, also has some characteristics of a sapropel. Although the carbonate content is the highest measured here, the organic carbon content is also high and the $\mathrm{Br}$ and $\mathrm{Mo}$ contents are higher than in the adjacent samples. This sample contains abundant coccoliths, as discussed above.

\section{Minor Metal Enrichments in Sapropelic Sediments}

The enrichment of several transition metals in finegrained, organic-rich marine sediments frequently has been observed. Correlations between metal concentrations and organic carbon have been used to infer a structural association between the metals and sedimentary organic matter (Curtis, 1966) although such correlations could also be produced by the association of the metals with a separate phase in sediments containing relatively high concentrations of organic carbon (Calvert, 1976). In the sapropelic sediments from the Black Sea, and also for example in the organic-rich near-shore muds on the Namibian shelf (Calvert and Price, 1970), it seems clear that a supply, or supplies, of metals from different terrigenous sources must be involved simply because the terrigenous component of the sediments is of relatively minor importance.

Among the minor elements showing enrichment in the Black Sea sapropels, Mo has the highest concentration relative to other Black Sea sediments and to nearshore clays and shales in general. Such an enrichment is shown by other moderately organic-rich sediments which are accumulating in basins having free sulfide, either permanently or intermittently, in the water overlying the sediment (Calvert, 1976).

Factors controlling the deposition of Mo in marine sediments have been examined from several points of view. Krauskopf (1956) concluded that it was unlikely that the concentration of Mo in seawater is controlled by the precipitation of the sulfide because of the relatively high solubility of both $\mathrm{MoS}_{2}$ and $\mathrm{MoS}_{3}$. 
S. E. CALVERT, C. E. BATCHELOR

TABLE 4

Spearman Rank Correlation Coefficient Matrix for Major and Minor Element Data Hole 379A, Leg 42B

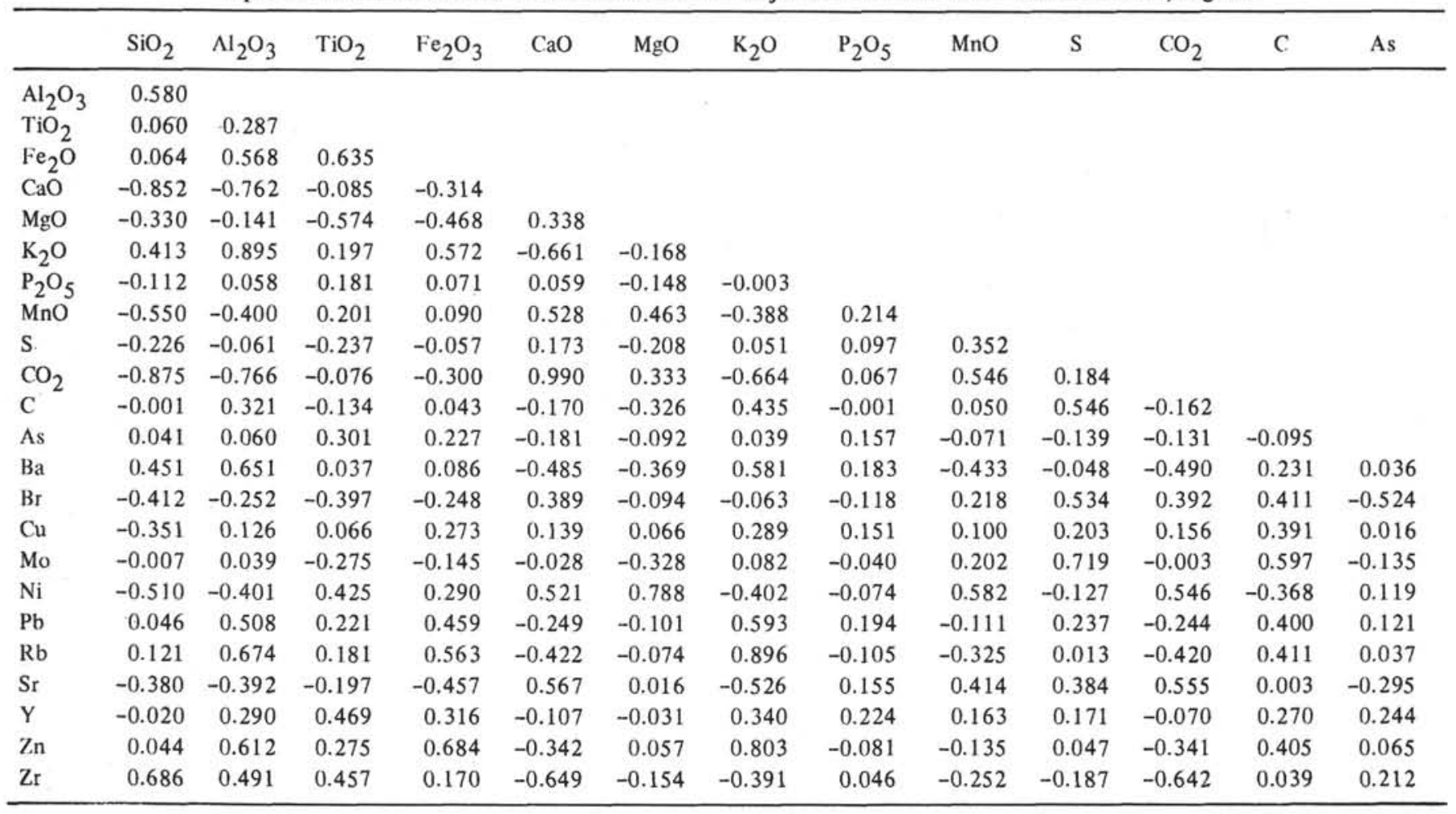

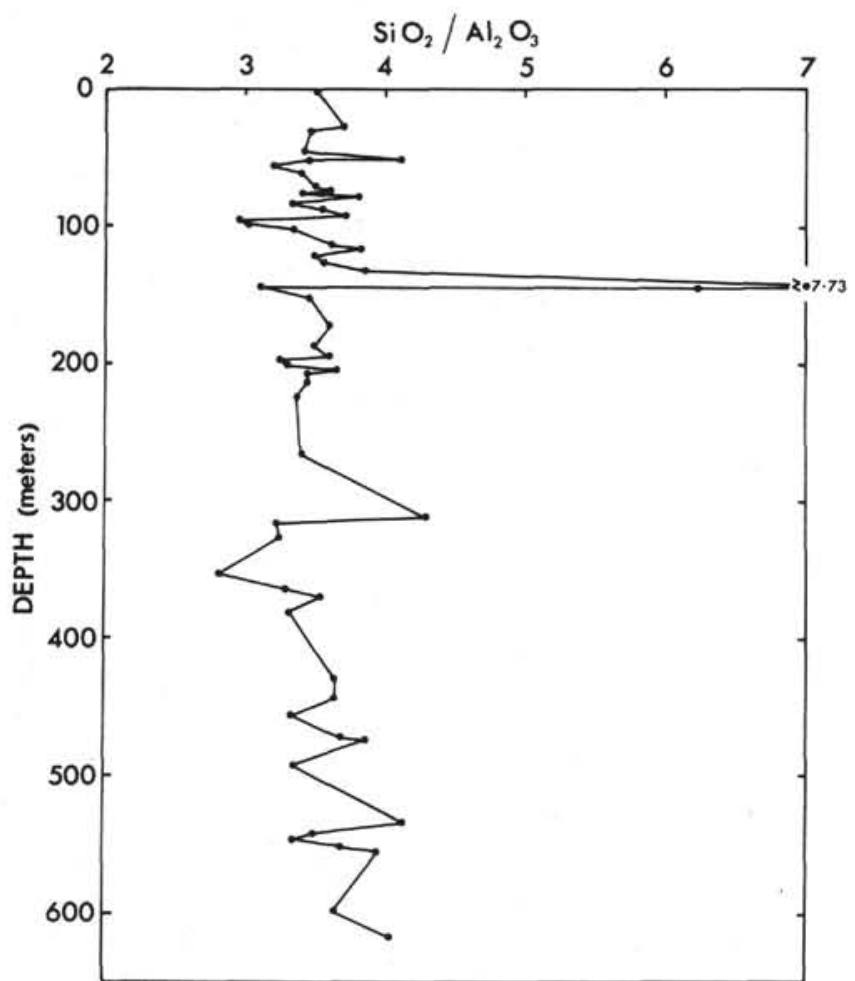

Figure 4. Vertical distribution of $\mathrm{SiO}_{2} / \mathrm{Al}_{2} \mathrm{O}_{3}$ ratio of the bulk sediment at Hole $379 \mathrm{~A}$.

Furthermore, Crecelius (1969) pointed out that if sulfide precipitation were an important mechanism for controlling the concentration of metals in organic-rich sediments, then the concentrations of $\mathrm{Ag}, \mathrm{Cu}, \mathrm{Pb}$, and

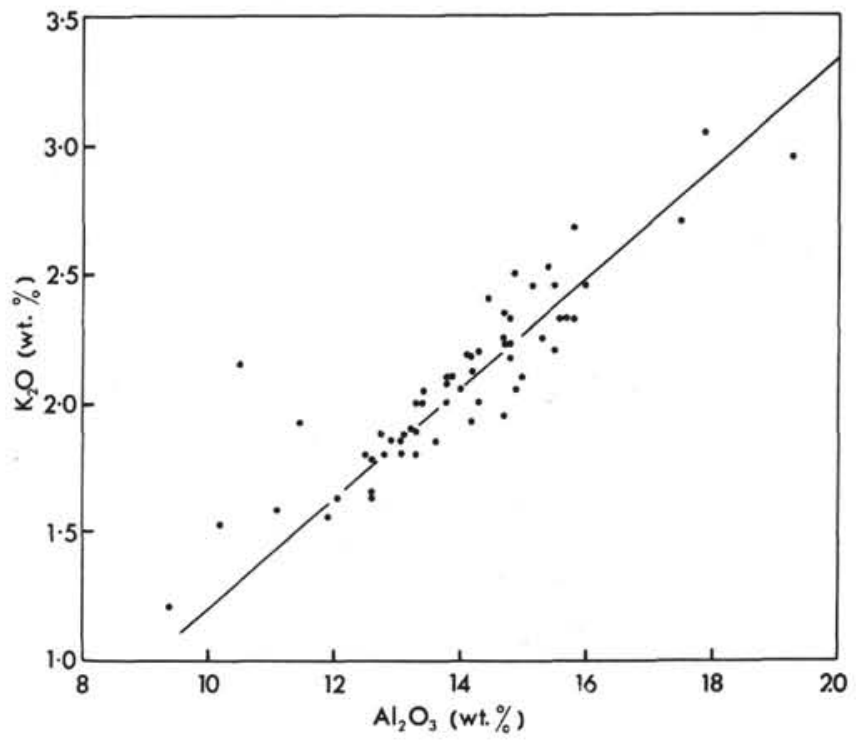

Figure 5. Relationship between $\mathrm{K}_{2} \mathrm{O}$ and $\mathrm{Al}_{2} \mathrm{O}_{3}$ contents of the sediments.

$\mathrm{Zn}$ should be higher than those of Mo from the solubilities of the sulfides of these metals.

Experimental work by Korolev (1968) and Bertine (1972) has shown, however, that Mo is rapidly removed from solutions of thiomolybdate by co-precipitation with FeS. Bertine suggested that the precipitate was amorphous $\mathrm{FeS} . \mathrm{MoS}_{3}$ which could later crystallize to tetragonal FeS (mackinawite) and MoSs. Korolev recognized that the Mo would not be present in the pyrite structure because of the large difference in ionic 
TABLE 4 - Continued

\begin{tabular}{|c|c|c|c|c|c|c|c|c|c|c|}
\hline & $\mathrm{Ba}$ & $\mathrm{Br}$ & $\mathrm{Cu}$ & Mo & $\mathrm{Ni}$ & $\mathrm{Pb}$ & $\mathrm{Rb}$ & $\mathrm{Sr}$ & $\mathrm{Y}$ & $\mathrm{Zn}$ \\
\hline \multicolumn{11}{|c|}{$\mathrm{Al}_{2} \mathrm{O}_{3}$} \\
\hline \multicolumn{11}{|c|}{$\mathrm{TiO}_{2}{ }^{\mathrm{O}}$} \\
\hline \multicolumn{11}{|c|}{$\mathrm{Fe}_{2} \mathrm{O}_{3}$} \\
\hline \multicolumn{11}{|c|}{$\mathrm{CaO}$} \\
\hline \multicolumn{11}{|c|}{$\mathrm{MgO}$} \\
\hline \multicolumn{11}{|c|}{$\mathrm{K}_{2} \mathrm{O}$} \\
\hline \multicolumn{11}{|c|}{$\mathrm{P}_{2} \mathrm{O}_{5}$} \\
\hline \multicolumn{11}{|c|}{$\mathrm{MnO}$} \\
\hline \multicolumn{11}{|l|}{$\mathrm{S}$} \\
\hline \multicolumn{11}{|c|}{$\mathrm{CO}_{2}$} \\
\hline \multicolumn{11}{|l|}{$\mathrm{C}^{2}$} \\
\hline \multicolumn{11}{|l|}{ As } \\
\hline \multicolumn{11}{|l|}{$\mathrm{Ba}$} \\
\hline $\mathrm{Br}$ & -0.185 & & & & & & & & & \\
\hline $\mathrm{Cu}$ & 0.074 & 0.236 & & & & & & & & \\
\hline Mo & 0.086 & 0.364 & 0.116 & & & & & & & \\
\hline $\mathrm{Ni}$ & -0.536 & 0.026 & 0.140 & -0.270 & & & & & & \\
\hline $\mathrm{Pb}$ & 0.319 & 0.046 & 0.442 & 0.225 & -0.243 & & & & & \\
\hline $\mathrm{Rb}$ & 0.363 & 0.063 & 0.385 & -0.021 & -0.245 & 0.564 & & & & \\
\hline $\mathrm{Sr}$ & -0.098 & 0.320 & -0.113 & 0.330 & 0.143 & -0.300 & -0.622 & & & \\
\hline Y & 0.163 & 0.016 & 0.307 & 0.170 & 0.096 & 0.436 & 0.339 & -0.181 & & \\
\hline $\mathrm{Zn}$ & 0.306 & 0.072 & 0.541 & 0.028 & -0.081 & 0.594 & 0.889 & -0.558 & 0.393 & \\
\hline $\mathrm{Zr}$ & 0.365 & -0.421 & -0.161 & 0.023 & -0.299 & 0.269 & 0.209 & -0.359 & 0.393 & 0.145 \\
\hline
\end{tabular}

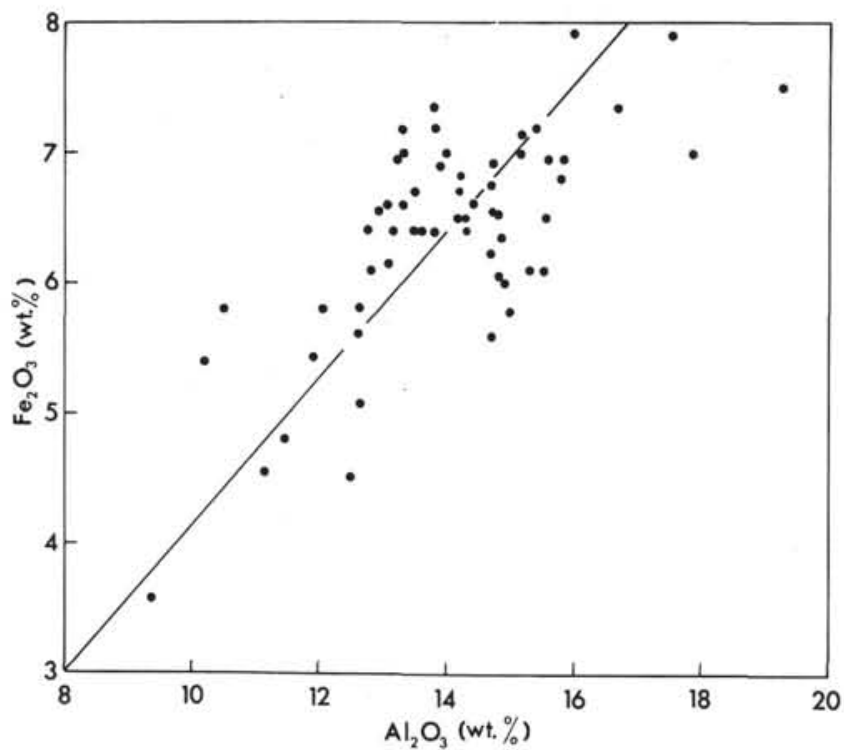

Figure 6. Relationship between the $\mathrm{Fe}_{2} \mathrm{O}_{3}$ and $\mathrm{Al}_{2} \mathrm{O}_{3}$ contents of the sediments.

sizes between $\mathrm{Mo}$ and $\mathrm{Fe}$ (see also Mohr, 1959). Sugawara et al. (1961) earlier suggested that the coprecipitation of Mo by FeS could explain the seasonal cycle of dissolved Mo in a Japanese lake and verified this process experimentally.

In contrast to the evidence for the importance of sulfide precipitation as a mechanism for increasing the concentration of Mo in marine sediments, Pilipchuk and Volkov $(1966,1968)$ and Crecelius (1969) have obtained evidence suggesting that a large proportion of the Mo in sediments is associated with the humic acid fraction of the organic material. Several metals,

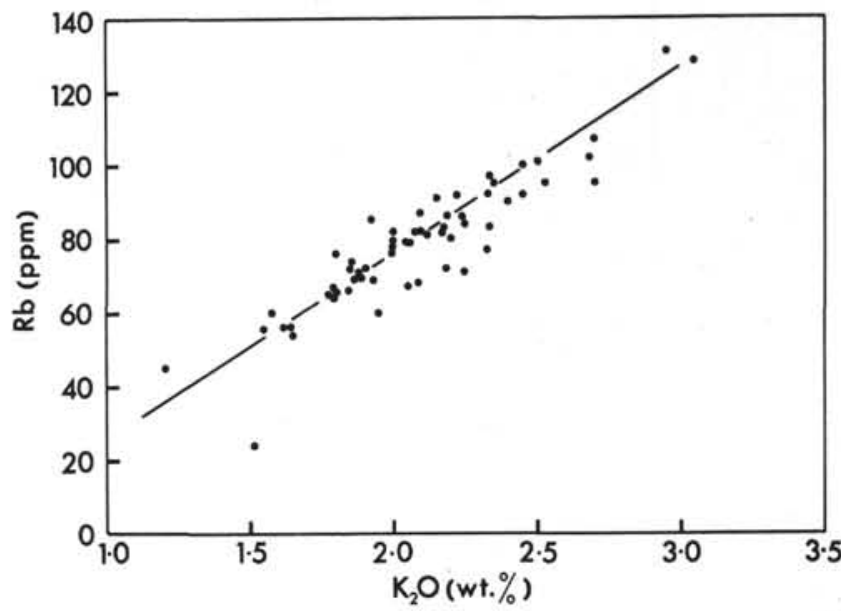

Figure 7. Relationship between the $\mathrm{K}_{2} \mathrm{O}$ and $\mathrm{Rb}$ contents of the sediments.

including Mo, are known to be organically bound in a variety of materials, including decomposing plant material (Bloomfield and Kelso, 1973), peat (Szitagyi, 1967; Szalay and Szilagyi, 1967), coal (Kuznetsova and Saukov, 1961), and soils (Manskaya and Drozdova, 1968; Gamble and Schnitzer, 1973), and the high complexing capacity of marine humic acids has been reported by Rashid (1971). Volkov and Fomina (1971) have suggested that some proportion of the $\mathrm{Cu}, \mathrm{Co}, \mathrm{Ni}$, and $\mathrm{V}$ in Black Sea sediments is organically bound and that the metals are extracted from the water by settling action.

A solution to this confusing picture is provided by observations on the distribution of Mo in Holocene Black Sea sediments by Volkov and Fomina (1974). 


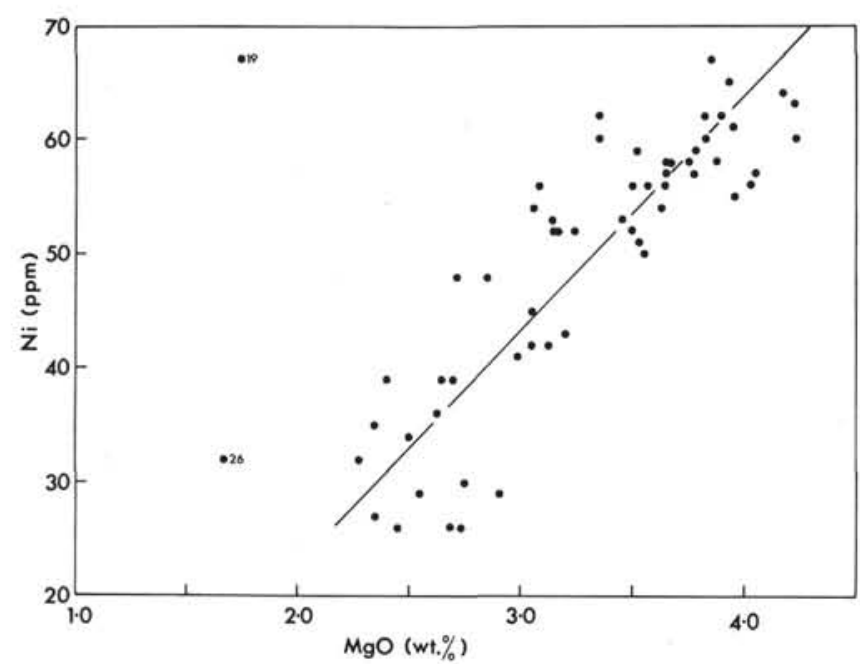

Figure 8. Relationship between $\mathrm{MgO}$ and $\mathrm{Ni}$ contents of the sediments. Numbers are sample numbers as given in Tables 1 and 3.

The concentration of Mo in the humic acid fraction of the sediments is overestimated if the humic fraction is extracted with $0.1 \mathrm{~N} \mathrm{NaOH}$, the method used by
Volkov and Fomina, because Mo is also removed from pyrite by this same procedure. Analyses of pyrite separated from Holocene and Neoeuxinian sediments from the Black Sea (Table 5) confirm the high concentrations of Mo and some other metals in modern pyrite. On the other hand, pre-Holocene pyrite contains much lower amounts of these same metals. The high concentrations of $\mathrm{Mo}$ and $\mathrm{Cu}$ in the modern pyrite compared with $\mathrm{Ni}$ are not readily explained by substitution because of the difference in ionic sizes between minor metals and Fe (Mohr, 1959). For this reason, Volkov and Fomina (1974) suggested that the Mo is present on the surface of the pyrite as thinly dispersed $\mathrm{MoS}_{3}$ and is therefore readily removed by treating unground pyrite with $\mathrm{NaOH}$. However, the data in Table 5 suggest that if the high concentration of Mo in Black Sea sapropels is due to the presence of Mo in pyrite, then the sapropels should have even higher concentrations of $\mathrm{Cu}$ and $\mathrm{Ni}$, which is not the case.

In Hole $379 \mathrm{~A}$, the sapropel contains $175 \mathrm{ppm}$ Mo and $1.81 \% \mathrm{~S}$ (Table 3). Therefore, if all the Mo is present in, or associated with, pyrite, the pyrite would contain approximately $0.5 \% \mathrm{Mo}$. This is a rather high figure in comparison with the data and observations on Holocene pyrite discussed above and more especially so

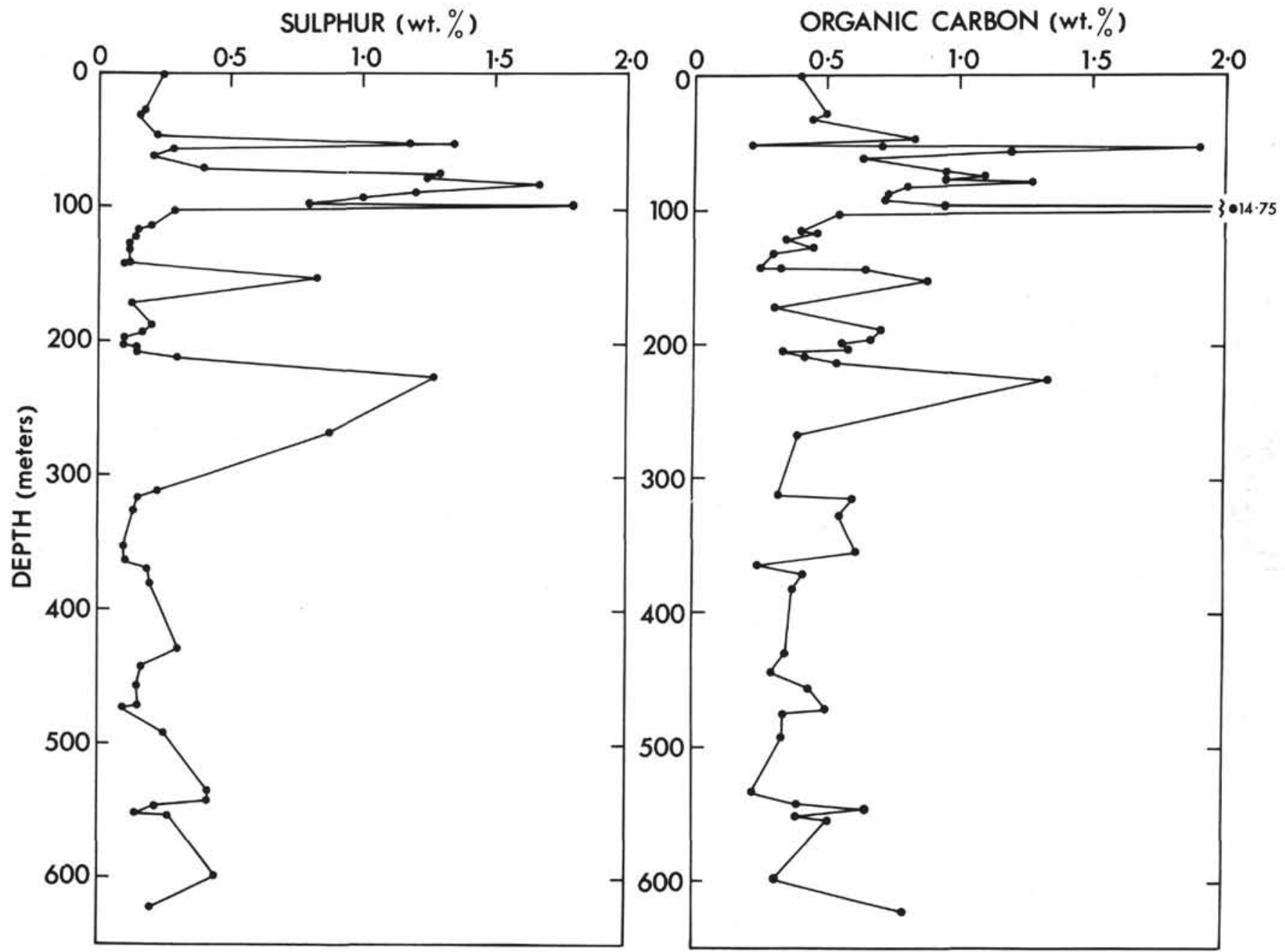

Figure 9. Vertical distribution of total sulfur and organic carbon at Hole $379 \mathrm{~A}$. 
TABLE 5

Concentrations of Minor Elements (ppm) in Pyrite from Holocene and Neoeuxinian Black Sea Sediments

\begin{tabular}{lrrr}
\hline & Holocene & \multicolumn{2}{c}{ Neoeuxinian } \\
Element & $1^{\mathrm{a}}$ & $2^{\mathrm{b}}$ & $3^{\mathrm{c}}$ \\
\hline As & & & 876 \\
$\mathrm{Co}$ & 134 & 67 & 173 \\
$\mathrm{Cr}$ & & & 35 \\
$\mathrm{Cu}$ & 1022 & 90 & 186 \\
$\mathrm{Mo}$ & 664 & 14 & \\
$\mathrm{Ni}$ & 1182 & 162 & 143 \\
$\mathrm{~Pb}$ & & & 307 \\
$\mathrm{~V}$ & & & 121 \\
$\mathrm{Zn}$ & & & 108 \\
\hline $\mathrm{a} 1$ From Volkov and Fomina (1972). \\
b From Volkov and Fomina (1972). \\
c From 3 From Butuzova (1969).
\end{tabular}

since we are dealing here with pre-Holocene sediments where pyrite apparently contains much lower amounts of Mo. The different concentrations of minor metals in Holocene and Neoeuxinian sediments (Table 5) may be due to different sources or availabilities of the metals (Volkov and Fomina, 1974) or to the post-depositional mobilities of the metals. In the latter case, minor metals may be initially concentrated in sediments by coprecipitation in sulfide-bearing waters and subsequently migrate and become bound with dispersed organic matter in the same sediments. This would explain the frequent reports of associations between metals and organic matter and the lack of correlation between metal and sulfur contents in such sediments (see Pilipchuk and Volkov, 1968; Volkov and Fomina, 1974).

On the basis of this evidence, it is concluded that the minor metals which are enriched in the sapropel at Hole $379 \mathrm{~A}$ are associated predominantly with the organic matter in the sediment rather than the sulfide. An unequivocal method for distinguishing between the two possible metal hosts in sediments is clearly required.

The sapropel at Hole $379 \mathrm{~A}$ also has higher concentrations of $\mathrm{Mn}$ compared with the other horizons. In the Holocene sediments, Mn concentrations also reach high values at horizons within and slightly below the sapropels (Hirst, 1974). Hence, Mn enrichment has occurred immediately before and during the early stages of the wholesale stagnation of the Black Sea. It is most unlikely that the $\mathrm{Mn}$ is present as an oxide, as suggested by Hirst (1974), because of the solubility of such a phase under lowered redox potentials. The $\mathrm{Mn}$ is probably present as manganese (II) carbonate, or a mixed calcium-manganese carbonate, ${ }^{1}$ a phase found in mildly reducing and oxidizing sediments where there is free oxygen in the overlying water (Calvert, 1976).

The sapropel (Sample 19) also has the highest concentration of $\mathrm{P}_{2} \mathrm{O}_{5}$ (Table 3). Similarly high $\mathrm{P}_{2} \mathrm{O}_{5}$

\footnotetext{
'This is confirmed by the presence in this horizon of Mn-bearing siderite, identified by X-ray diffraction (P. Stoffers, personal communication).
}

values are found in organic-rich diatomaceous oozes from the Namibian shelf (Veeh et al., 1973) due to the presence of fine-grained phosphorite. Such an authigenic phase may also account for the high $\mathrm{P}_{2} \mathrm{O}_{5}$ value in the sapropel sample analyzed here, the $\mathrm{P}$ being derived from the breakdown of the abundant organic matter at this horizon.

\section{Halogens}

As pointed out previously, $\mathrm{Br}$ and $\mathrm{I}$ are present exclusively in the organic fraction of the sediment (see Vinogradov, 1939). Bromine is present at concentrations above the limit of detection $(1 \mathrm{ppm})$ at all horizons at Hole 379A, whereas I is below the limit of detection (also $1 \mathrm{ppm}$ ) in slightly more than half the samples (Table 3). The $\mathrm{I} / \mathrm{Br}$ ratio is less than unity throughout the core. Samples 8 and 19, previously shown to be carbonate- and organic-rich, respectively, are markedly enriched in $\mathrm{Br}$, but $\mathrm{I}$ is not enriched at these same horizons. The I concentrations given in Table 3 may be compared with values of $44 \mathrm{ppm}$ in gray clays and $49 \mathrm{ppm}$ in sapropels from Holocene Black Sea sediments reported by Shishkina and Pavlova (1965).

In oxidized marine sediments, the $\mathrm{I} / \mathrm{Br}$ ratio appears to be substantially greater than unity (Price et al., 1970; Price and Calvert, 1973), whereas in reduced marine sediments this ratio falls to values less than unity (Price and Calvert unpublished). In lake sediments, the $\mathrm{I} / \mathrm{Br}$ ratio is also less than unity (Mun and Bazilevich, 1964). Hence, the I/ $\mathrm{Br}$ ratio in the sediments from Hole $379 \mathrm{~A}$ could be explained both by the reducing nature of the sediment and by the fact that most of the sediments sampled were deposited under lacustrine conditions. However, as pointed out by Mun and Bazilevich (1964), $\mathrm{Br}$ is fixed on sediment organic matter more firmly than is $\mathrm{I}$ so that during diagenesis the $\mathrm{I} / \mathrm{Br}$ ratio in the pore water increases while the $\mathrm{I} / \mathrm{Br}$ ratio in the solid phase decreases. Some alteration of the original ratio in the bulk sediment has therefore most probably taken place, but an explanation of the actual levels of $\mathrm{I}$ and $\mathrm{Br}$ in these sediments must await a more extensive study of the concentrations of $\mathrm{I}$ and $\mathrm{Br}$ in the Recent sediments throughout the Black Sea.

\section{FACTOR ANALYSIS OF THE CHEMICAL DATA}

An R-mode factor analysis of the total major and minor element data confirms most of the element associations deduced from the correlation matrix, and provides a summary of the interelement relationships. After the principal components analysis, 5 factors accounted for $97.5 \%$ of the total variance. The factor loadings for these 5 factors are shown in Table 6 .

Factor 1 represents the carbon, minor metal, S, $\mathrm{MnO}$, and $\mathrm{Br}$ association, with additional high loadings for $\mathrm{P}_{2} \mathrm{O}_{5}$ and $\mathrm{Sr}$. It represents organic- and sulfide- rich samples which also have high $\mathrm{Sr}$ contents because of the presence of coccoliths and aragonite. These horizons also contain small amounts of manganoan calcite and phosphorite.

Factor 2 has high loadings for $\mathrm{K}_{2} \mathrm{O}, \mathrm{Al}_{2} \mathrm{O}_{3}, \mathrm{Fe}_{2} \mathrm{O}_{3}$, $\mathrm{Rb}, \mathrm{Pb}, \mathrm{Y}$, and $\mathrm{Zn}$ and moderately high loadings for $\mathrm{TiO}_{2}$ and $\mathrm{Ba}$. This factor is identified as feldspar. 
TABLE 6

Quartimax Factor Matrix for Major and Minor Element Data From Hole 379A, Leg 42Ba

\begin{tabular}{|c|c|c|c|c|c|}
\hline \multirow[b]{2}{*}{ Element } & \multicolumn{5}{|c|}{ Factors } \\
\hline & 1 & 2 & 3 & 4 & 5 \\
\hline $\mathrm{SiO}_{2}$ & -0.47 & & -0.81 & & \\
\hline $\mathrm{Al}_{2} \mathrm{O}_{3}$ & & 0.81 & -0.41 & & \\
\hline$\cdot \mathrm{TiO}_{2}$ & -0.39 & 0.48 & & 0.52 & 0.58 \\
\hline $\mathrm{Fe}_{2} \mathrm{O}_{3}$ & & 0.77 & & 0.49 & \\
\hline $\mathrm{CaO}$ & & & 0.95 & & \\
\hline $\mathrm{MgO}$ & -0.31 & & & 0.86 & \\
\hline $\mathrm{K}_{2} \mathrm{O}$ & & 0.91 & & & \\
\hline $\mathrm{P}_{2} \mathrm{O}_{5}$ & 0.51 & & & & 0.31 \\
\hline $\mathrm{MnO}$ & 0.79 & & & & \\
\hline $\mathrm{S}$ & 0.48 & & & & \\
\hline $\mathrm{CO}_{2}$ & & & 0.92 & & \\
\hline $\mathrm{C}$ & 0.99 & & & & \\
\hline As & -0.90 & & & & \\
\hline $\mathrm{Ba}$ & & 0.41 & & & -0.44 \\
\hline $\mathrm{Br}$ & 0.96 & & & & \\
\hline $\mathrm{Cu}$ & 0.89 & & & & \\
\hline Mo & 0198 & & & & \\
\hline $\mathrm{Ni}$ & & & & 0.95 & \\
\hline $\mathrm{Pb}$ & & 0.72 & & & \\
\hline $\mathrm{Rb}$ & 0.33 & 0.83 & & & \\
\hline $\mathrm{Sr}$ & 0.71 & & 0.43 & & \\
\hline $\mathrm{Y}$ & 0.36 & 0.60 & & & 0.36 \\
\hline $\mathrm{Zn}$ & & 0.68 & & & \\
\hline $\mathrm{Zr}$ & -0.31 & & -0.66 & & \\
\hline $\begin{array}{l}\text { Cumula- } \\
\text { tive \% } \\
\text { variance } \\
\text { explained }\end{array}$ & 43.1 & 66.2 & 84.2 & 93.2 & 97.5 \\
\hline
\end{tabular}

${ }^{\mathrm{a}}$ Loadings less than 0.30 omitted.

Factor 3 is a bipolar factor, containing positive loadings for $\mathrm{CaO}, \mathrm{CO}_{2}$, and $\mathrm{Sr}$ and negative loadings for $\mathrm{SiO}_{2}, \mathrm{Al}_{2} \mathrm{O}_{3}$, and $\mathrm{Zr}$. It represents the negative correlation between the amounts of $\mathrm{CaCO}_{3}$ and sand throughout the hole (see Figures 1 and 4). A plot of the Factor 1 and 3 loadings (Figure 10) shows the relationship between the carbonate, sand and carbonsulfide groups.

Factor 4 is interpreted as the chlorite factor, with high loadings for $\mathrm{MgO}$ and $\mathrm{Ni}$ and moderately high loadings for $\mathrm{TiO}_{2}$ and $\mathrm{Fe}_{2} \mathrm{O}_{3}$. A plot of the Factor 2 and 4 loadings (Figure 11) shows the relationship between these two factors and the partition of $\mathrm{TiO}_{2}$ and $\mathrm{Fe}_{2} \mathrm{O}_{3}$ between chlorite and other aluminosilicates.

Factor 5 contains significant loadings for $\mathrm{TiO}_{2}, \mathrm{P}_{2} \mathrm{O}_{5}$, $\mathrm{Y}$, and $\mathrm{Zr}$. It probably represents a heavy mineral association, with ilmenite, zircon, monazite, and apatite the most likely minerals.

\section{EVIDENCE FOR MARINE AND LACUSTRINE CONDITIONS AT HOLE 379A}

As indicated in the Introduction, a section through the Pleistocene sediments in the Black Sea provides an opportunity to study the record of changes in the

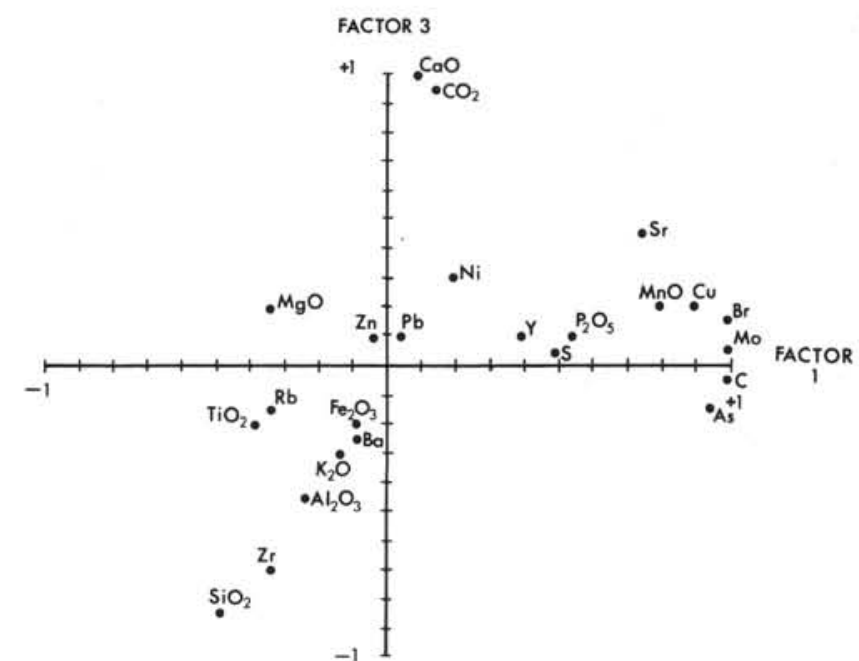

Figure 10. Relationship between Factor 1 and 3 loadings.

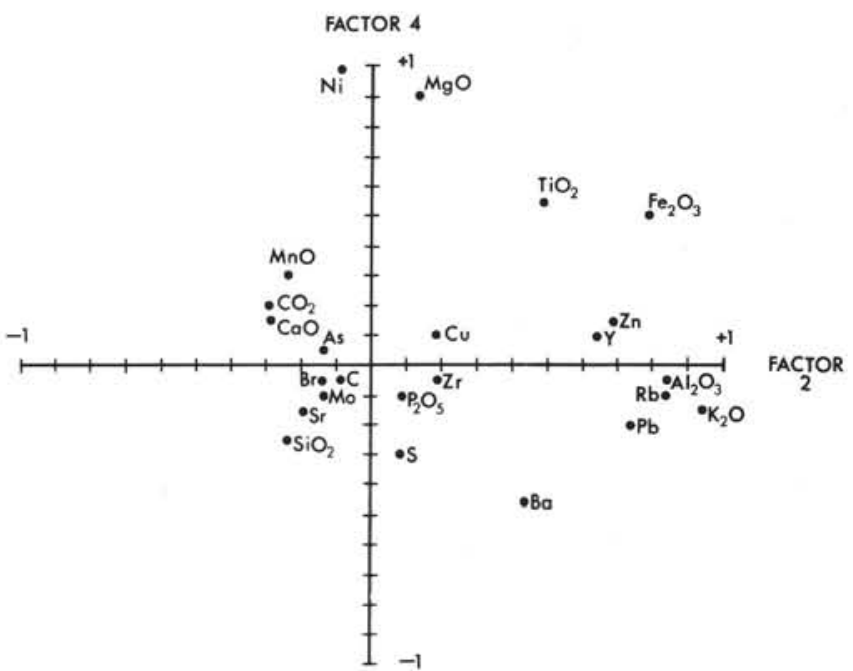

Figure 11. Relationship between Factor 2 and 4 loadings.

hydrography of a basin based on the geochemistry of the accumulated sediments. The Pleistocene sediments recovered at Hole 379A are for the most part terrigenous silts and clays, with occasional sand layers and sapropelic and carbonate-bearing horizons, showing few distinct compositional changes with depth that can be related to possible changes in the composition of the water filling the basin. The variations in the concentrations of $\mathrm{Br}$ and $\mathrm{I}$, which could potentially be used to distinguish oxic and anoxic conditions, and possibly marine and lacustrine environments, have most probably been altered from their original values, as discussed in a previous section.

Degens and Ross (1972) have suggested that the distinctive sapropel in the modern sediments of the Black Sea was probably deposited during a period of increasing saline water influx into the late Pleistocene lake from the Mediterranean. Earlier sapropels and organic- and pyrite-rich muds most probably represent similar periods when the water in the lake changed from fresh to saline. Four such horizons can be recognized at Hole $379 \mathrm{~A}$; namely $6-5,123-125 \mathrm{~cm}$ (Sample 8); 11-5, 52-61 cm (Sample 19); 20-3, 80-86 cm 
(organic-rich mud); 29-4, 127-134 cm and 29-5, 0-13 cm (sapropels). The positions of these organic-rich horizons coincide with maxima in the pore water chlorinity curve as given by Manheim (this volume) which are themselves considered to indicate saline water influxes. Hence, some marine influences appear to be recorded in the sediments.

Additional information is provided by the distribution of sulfur in the bulk sediments. The concentration of total sulfur, corrected for pore-water sulfate as described above, is thought to be a reflection of the amount of pyrite in the sediment. Since the concentration of pyrite in a sediment is governed, among other factors, by the supply of sulfate from sea water (see Berner, 1970), more pyrite is likely to be produced in a marine environment as compared with a freshwater environment. Hence, the variation in sulfur content, as shown in Figure 9, reflects the presence of marine and lacustrine conditions in the Black Sea over the period represented by the core. This variation is combined, in Figure 12, with the pore water data and the occurrence of sapropels to show the distribution of these lithological and chemical variations down the core. The tentative identification of the marine horizons is also shown. This is confirmed by the occurrence of marine diatoms in Cores 10, 11, 18, 23, 25 , and 29 (Schrader, this volume), corresponding to the three pre-Recent marine intervals indicated in Figure 12. In addition, Braarudosphaera bigelowi, a form indicating brackish water conditions, occurred abundantly in Core 25 and rare individual specimens occurred in Cores 19, 21, 25, and 51 (Percival, this volume).

On the basis of this evidence, three major marine horizons, in addition to the modern one, are present in the upper half of the core. The lower half of the core represents fresh-water sediment, although the pore water chlorinity increases with depth below about 350 meters due to diffusion of chloride from a deeper hypersaline interval (see Manheim, this volume).

\section{ACKNOWLEDGMENTS}

We thank David Ross for making arrangements for the collection of the samples and Peter Stoffers and Egon Degens

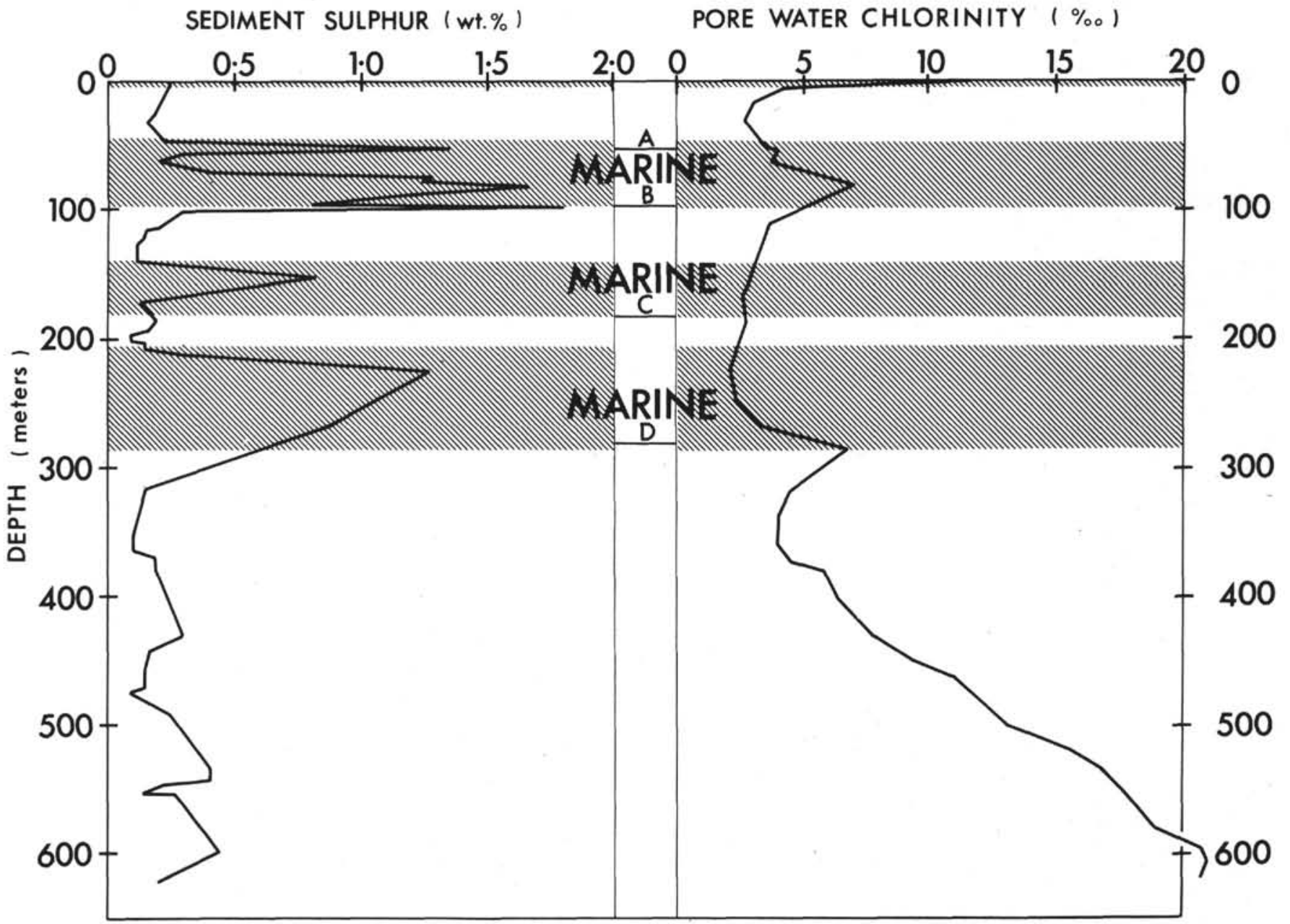

Figure 12. Tentative identification of marine and lacustrine horizons at Hole 379A based on the distribution of sulfur in the bulk sediment (left), the chlorinity of the pore water (from Manheim, this volume) (right), and the occurrence of sapropelic, coccolith-bearing or organic-rich sediments (center column). A = coccolith mud at 52.24 meters depth (sample 8); B = sapropel at 99.05 meters depth (sample 19); $C=$ organic-rich mud at 181.85 meters depth (not sampled); $D=$ sapropels between 268.23 and 268.68 meters (not sampled). 
for performing the sampling. We acknowledge valuable discussions with Peter Stoffers on the mineralogy of the sediments. Brian Funnel and Stephen Percival provided identifications of the nannofossils shown in Plate 1 .

\section{REFERENCES}

Berner, R.A., 1970. Sedimentary pyrite formation: Am. J. Sci., v. 268, p. 1-23.

Bertine, K.K., 1972. The deposition of molybdenum in anoxic waters: Marine Chem., v. 1, p. 43-53.

Bloomfield, C. and Kelso, W.I., 1973. The mobilization and fixation of molybdenum, vanadium and uranium by decomposing plant matter: J. Soil. Sci., v. 24, p. 367-379.

Butuzova, G.Y., 1969. Mineralogy and geochemistry of iron sulfides in Black Sea sediments: Litol. Polez. Iskop., no. 4, p. 3-16.

Calvert, S.E., 1976. The mineralogy and geochemistry of nearshore sediments. In Riley, J.P. and Chester, R. (Eds.), Chemical oceanography, 2nd Ed.: v. 6, p. 187-280.

Calvert, S.E. and Price, N.B., 1970. Minor metal contents of recent organic-rich sediments off South West Africa: Nature, v. 227-, p. 593-595.

Crecelius, E.A., 1969. Mo enrichment in the sediments of an anoxic fjord: Am. Geophys. Union Trans., v. 50, p. 208.

Curtis, C.D., 1966. The incorporation of soluble organic matter into sediments and its effect on trace element assemblages: In Hobson, G.D. and Louis, M.C. (Eds.), Advances in Organic Geochem: New York (Pergamon Press), p. 1-13.

Degens, E.T. and Ross, D.A., 1972. Chronology of the Black Sea over the last 25,000 years: Chem. Geol., v. 10, p. 1-16. 1974. The Black Sea-geology, chemistry and biology: Am. Assoc. Petrol. Geol., Mem. 20.

Fabbi, B.P., 1972. A refined fusion X-ray fluorescence technique, and determination of major and minor elements in silicate standards: Am. Mineralogist, v. 57, p. 237-245.

Gamble, D.S. and Schnitzer, M., 1973. The chemistry of fulvic acid and its reactions with metal ions. In Singer, P.C. (Ed.), Trace metals and metal-organic interactions in natural waters: Ann Arbor, Michigan (Ann Arbor Science Publ.), p. 265-302.

Heier, K.S., 1962. Trace elements in feldspars-a review: Norsk Geol. Tidssk., v. 42, p. 415-454.

Heier, K.S. and Adams, J.A.S., 1964. The geochemistry of the alkali metals. In Ahrens, L.H., Press, F., and Runcorn, S.K. (Eds.), Physics and chemistry of the earth: v. 5, p. 253-381.

Hirst, D.M., 1962. The geochemistry of modern sediments from the Gulf of Paria I: Geochim. Cosmochim. Acta, v. 26, p. $309-334$.

1974. Geochemistry of sediments from eleven Black Sea cores. In Degens, E.T., and Ross, D. A. (Eds.), The Black Sea-geology, chemistry and biology: Am. Assoc. Petrol. Geol. Mem. 20, p. 430-455.

Horstmann, E.L., 1957. The distribution of lithium, rubidium and cesium in igneous and sedimentary rocks: Geochim. Cosmochim. Acta, v. 12, p. 1-28.

Kinsman, D.J.J., 1969. Interpretation of $\mathrm{Sr}^{+2}$ concentrations in carbonate minerals and rocks: J. Sediment. Petrol., v. 39 , p. $486-508$.

Kolpack, R.L. and Bell, S.A., 1968. Gasometric determination of carbon in sediments by hydroxide absorption: J. Sediment. Petrol., v. 38, p. 617-620.

Korolev, D.F., 1958. The role of iron sulphides in the accumulation of molybdenum in sedimentary rocks of the reduced zone: Geokhimiya, no. 4, p. 452-463.

Krauskopf, K.B., 1956. Factors controlling the concentrations of thirteen rare metals in sea water: Geochim. Cosmochim. Acta, v. 9, p. 1-32.
1967. Introduction to geochemistry: New York (McGraw-Hill)

Kuznetsova, V.V. and Saukov, A.A., 1961. Possible forms of occurrence of molybdenum and rhenium in coals of Middle Asia: Geokhimiya, no. 9, p. 750-756.

Manskaya, S.M. and Drozdova, T.V., 1968. Geochemistry of organic substances: London (Pergamon Press).

Mohr, P.A., 1959. The distribution of some minor elements between sulphide and silicate phases of sediments: Contrib. Geophys. Observatory, Univ. College Addis Ababa, A-2, p. 1-18.

Müller, G. and Stoffers, P., 1974. Mineralogy and petrology of Black Sea basin sediments. In Degens, E.T. and Ross, D.A. (Eds.), The Black Sea-geology, chemistry and biology: Am. Assoc. Petrol. Geol., Mem. 20, p. 201-248.

Mun, A.I. and Bazilevich, Z.A., 1964. Some characteristics of the distribution of iodine in lake muds: Geokhimiya, v. 5, p. $468-476$.

Peterson, M.N.A. and Goldberg, E.D., 1962. Feldspar distributions in South Pacific pelagic sediments: J. Geophys. Res., v. 67, p. 3477-3492.

Petruk, W., 1964. Determination of the heavy atom content in chlorite by means of the X-ray diffractometer: Am. Mineralogist. v. 49, p. 61-71.

Pilipchuk, M.F. and Volkov, I.I., 1966. Distribution of molybdenum in recent sediments of the Black Sea: Dokl. Akad. Nank, S.S.S.R., v. 167, p. 152-157.

1968. The geochemistry of molybdenum in the Black Sea: Litol. Polez. Iskop., no. 4, p. 5-27.

Price, N.B. and Calvert, S.E., 1973. The geochemistry of iodine in oxidised and reduced recent marine sediments: Geochim. Cosmochim. Acta, v. 37, p. 2149-2158.

Price, N.B. Calvert, S.E., and Jones, P.G.W., 1970. The distribution of iodine and bromine in the sediments of the south-western Barents Sea: J. Mar. Res., v. 28, p. 22-34.

Rashid, M.A., 1971. Role of humic acids of marine origin and their different molecular weight fractions in complexing di- and tri-valent metals: Soil Sci., v. 111, p. 298-305.

Reynolds, R.C., 1963. Matrix corrections in trace element analysis by X-ray fluorescence: estimation of the mass absorption coefficient by Compton scattering: Am. Mineralogist, v. 48, p. 1133-1143.

Ribbe, P.H. and Smith, J.V., 1966. X-ray emission microanalysis of rock-forming minerals. IV. Plagioclase feldspars: J. Geol., v. 74, p. 217-233.

Sayles, F.L. and Manheim, F.T., 1975. Interstitial solutions and diagenesis in deeply buried marine sediments: results from the Deep Sea Drilling Project: Geochim. Cosmochim Acta, v. 39, p. 103-127.

Shishkina, O.V. and Pavlova, G.A., 1965. Iodine distribution in marine and oceanic bottom muds and their pore fluids: Geokhimiya, v. 6, p. 739-746.

Slemmons, D.B., 1962. Observations on order-disorder relations of natural plagioclase I. A method of evaluating order-disorder: Norsk Geol. Tidssk., v. 42, p. 533-554.

Smith, J.V. and Ribbe, P.H., 1966. X-ray emission microanalysis of rock-forming minerals. III Alkali feldspars: J. Geol., v. 74, p. 197-216.

Sugawara, K., Okabe, S., and Tanaka, M., 1961. Geochemistry of molybdenum in natural waters (II): J. Earth Sci., Nagoya Univ., v. 9, p. 114-128.

Szalay, A. and Szilagyi, M., 1967. The association of vanadium with humic acids: Geochim Cosmochim Acta, v. 31, p. $1-6$.

Szilagyi, M., 1967. Sorption of molybdenum by humus preparations: Geokhimiya, no. 12, p. 1489-1492.

Taylor, S.R., 1965. The application of trace element data to problems in petrology. In Ahrens, L.H., Press, F., Runcorn, S.K., and Urey, H.C. (Eds.), Physics and chemistry of the earth: v. 6, p. 133-213. 
Thompson, G. and Bowen, U.T., 1969. Analyses of coccolith ooze from the deep tropical Atlantic: J. Mar. Res., v. 27, p. $32-38$

Veeh, H.H., Calvert, S.E., and Price, N.B., 1974. Accumulation of uranium in sediments and phosphorites on the South West African shelf: Marine Chem., v. 2, p. 189-202.

Vinogradov, A.P., 1939. Iodine in marine oozes: origin of I$\mathrm{Br}$ waters in petroliferous areas: Trudy Biogeokhim. Lab. Akad. Nauk. S.S.S.R., v. 5, p. 19-32.
Volkov, I.I., and Fomina, L.S., 1971. Dispersed elements in sapropel of the Black Sea and their inter-relationship with organic matter: Litol. Polez. Iskop., no. 6, p. 3-15.

1972. The role of iron sulfides in the accumulation of minor elements in Black Sea sediments: Litol. Polez. Iskop., no. 2, p. 18-24.

1974. Influence of organic material and processes of sulfide formation on distribution of some trace elements in deep water sediments of Black Sea. In Degens, E.T. and Ross, D.A. (Eds.), The Black Sea-geology, chemistry and biology: Am. Assoc. Petrol. Geol. Mem. 20, p. 457-476. 
S. E. CALVERT, C. E. BATCHELOR

\section{PLATE 1}

Scanning electron photomicrographs, Hole 379A

Figure 1 Gephyrocapsa caribbeanica Boudreaux and Hay, Sample $8(6-5,123-125 \mathrm{~cm})$.

Figure 2 Aragonite grains, Sample $19(11-5,55 \mathrm{~cm})$.

Figure 3 Syracosphaera sp., Sample $19(11-5,55 \mathrm{~cm})$.

Figure $4 \quad$ Authigenic calcite grains, Sample 60-2, 119-120 $\mathrm{cm}$, a seekreide horizon containing $63 \% \mathrm{CaCO}_{3}$ (sample supplied by P. Stoffers). 


\section{PLATE 1}
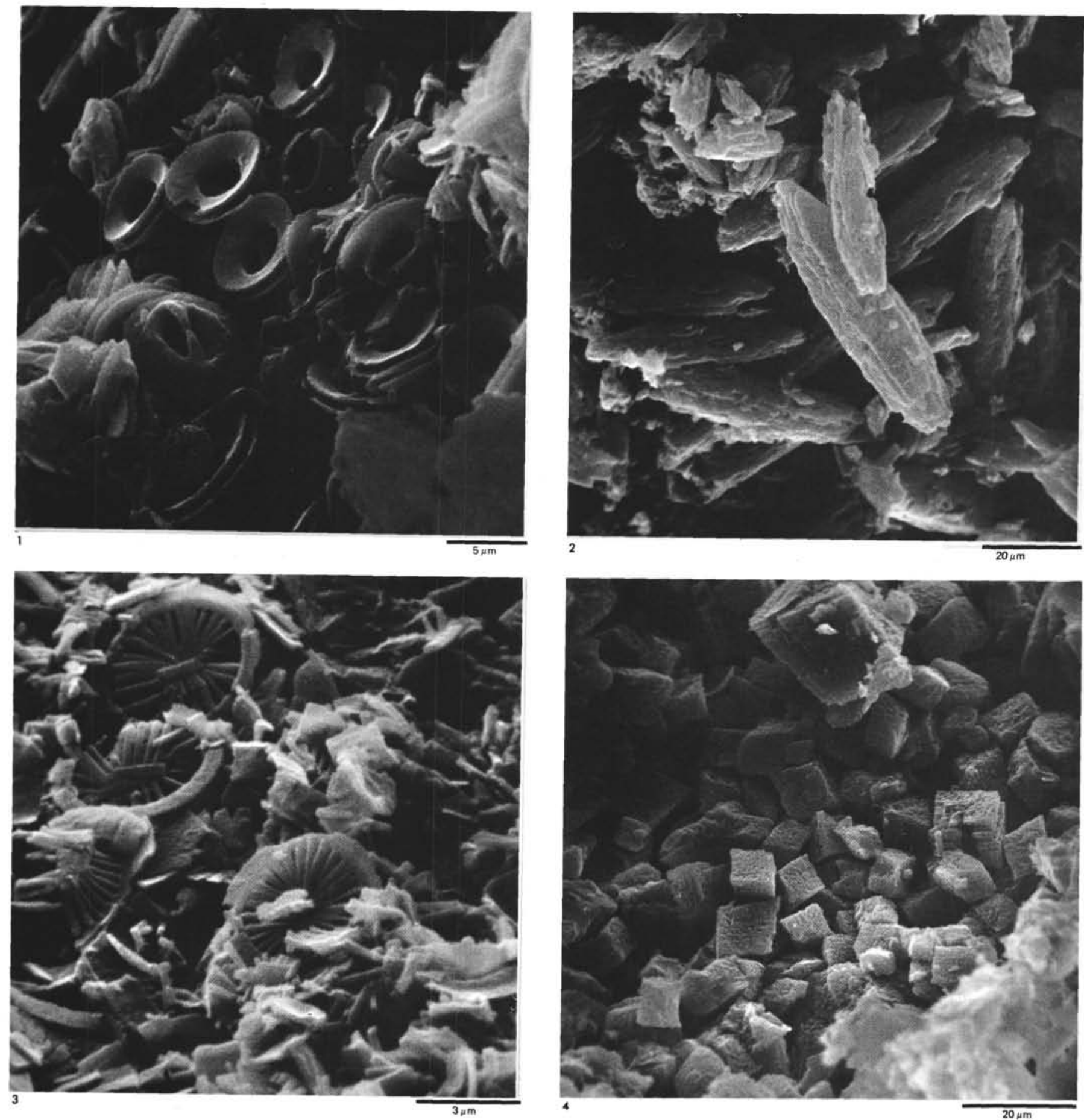